\title{
KARAKTERISTIK KADAR PROFIL LIPID PADA PENDERITA STROKE ISKEMIK DI RUMAH SAKIT IBNU SINA MAKASSAR TAHUN 2017 \\ Reski Amaliah ${ }^{1}$, Shulhana Mokhtar ${ }^{2}$, Hanna Aulia Namirah ${ }^{3}$, Mochammad Erwin Rachman ${ }^{4}$, Rachmat Faisal Syamsu ${ }^{5}$
}

1. Mahasiswa Program Studi Pendidikan Dokter, 2. Dosen Departemen Biokimia, 3. Dosen Departemen Anatomi, 4. Dosen Departemen Fisiologi, 5. Dosen Departemen IImu Kesehatan Masyarakat

Fakultas Kedokteran Universitas Muslim Indonesia

Email : reskiamaliah234@gmail.com

No.Telp : +6285240371647

\begin{abstract}
ABSTRAK
Masalah Penelitian : Menurut World Health Organization (WHO) adalah tanda-tanda klinis yang berkembang dengan cepat dari gangguan fokal dan fungsi serebral yang berlangsung lebih dari 24 jam dan dapat menyebabkan kematian tanpa penyebab yang jelas selain dari berasal dari vaskular. Angka kejadian stroke di Indonesia meningkat dengan tajam. Bahkan, saat ini Indonesia merupakan negara dengan jumlah penderita stroke terbesar di Asia. Salah satu faktor risiko dalam terjadinya penyakit vaskular ini adalah terbentuknya aterosklerosis yang disebabkan oleh kelainan metabolisme pada profil lipid darah yang ditandai dengan kenaikan kadar kolesterol total, trigliserida, kolesterol LDL serta penurunan kadar kolesterol HDL. Tujuan: Penelitian ini bertujuan untuk mengetahui karakteristik kadar profil lipid pada penderita stroke iskemik di Rumah Sakit Ibnu Sina Makassar tahun 2017. Metode: Jenis penelitian ini merupakan penelitian deskriptif untuk mengetahui karakteristik kadar profil lipid pada penderita stroke iskemik di Rumah Sakit Ibnu Sina Makassar pada tahun 2017. Pendekatan yang digunakan pada desain penelitian ini adalah cross sectional study, yaitu peneliti melakukan observasi dengan mengambil data dari rekam medik kemudian menilai variabel penelitian yang akan diteliti. Hasil penelitian tersebut akan diolah dengan menggunakan program Microsoft Office Excel. Hasil: Berdasarkan data sekunder yang diperoleh dari rekam medik Rumah Sakit Ibnu Sina Makassar, jumlah pasien stroke iskemik selama tahun 2017 yang berhasil tercatat sebanyak 54 orang dengan rincian 25 orang laki-laki dan 29 orang perempuan. Didapatkan adanya peningkatan kadar kolesterol dari nilai normal pada kolesterol total sebanyak $63 \%$, LDL sebanyak $57 \%$, dan trigliserida sebanyak $33 \%$. Sedangkan pada HDL didapatkan penurunan kadar kolesterol dari nilai normal sebanyak 39\%. Kesimpulan: Didapatkan adanya perubahan kadar profil lipid pada penderita stroke iskemik khususnya pada kolesterol total dan LDL yang ditandai dengan adanya peningkatan kadar kolesterol diatas nilai normal. Sedangkan pada profil lipid khususnya HDL dan trigliserida masih dalam batas nilai normal.
\end{abstract}

Kata Kunci: Stroke Iskemik, Profil Lipid. 


\section{Pendahuluan}

\section{Latar Belakang}

Definisi stroke menurut World Health Organization (WHO) adalah tanda-tanda klinis yang berkembang dengan cepat dari gangguan fokal dan fungsi serebral yang berlangsung lebih dari 24 jam dan dapat menyebabkan kematian tanpa penyebab yang jelas selain dari berasal dari vaskular. WHO memperkirakan bahwa 15 juta orang menderita stroke setiap setiap tahun, dan dari jumlah ini, 5 juta orang diperkirakan mengalami cacat permanen. ${ }^{1}$

Sekitar $80 \%$ dari stroke adalah stroke iskemik, dan sekitar $10 \%$ adalah stroke hemoragik. Insiden stroke meningkat seiring pertambahan usia. Angka kejadian stroke di Indonesia meningkat dengan tajam. Bahkan, saat ini Indonesia merupakan negara dengan jumlah penderita stroke terbesar di Asia. Di Indonesia penyakit ini menduduki posisi ketiga setelah jantung dan kanker. Sebanyak $28,5 \%$ penderita stroke meninggal dunia. Sisanya menderita kelumpuhan sebagian maupun total. Hanya $15 \%$ saja yang dapat sembuh total dari serangan stroke atau kecacatan. Yayasan stroke Indonesia (Yastroki) menyebutkan bahwa 63,52 per 100.000 penduduk Indonesia berumur di atas 65 tahun ditaksir terjangkit stroke. Penyebab stroke adalah gangguan pada aliran pembuluh darah di otak, beberapa hal dapat disebabkan antara lain oleh terbentuknya sumbatan pada pembuluh darah arteri maupun pecahnya pembuluh darah arteri yang menyebabkan terhentinya aliran suplai darah ke otak yang dapat diketahui salah satunya melalui pemeriksaan CT Scan. ${ }^{2,3}$

Kolesterol merupakan lipid amfipatik yang penting dalam pengaturan permeabilitas dan fluiditas membran, dan juga sebagai lapisan luar lipoprotein plasma. High Density Lipoprotein (HDL) kolesterol dan Low Density Lipoprotein (LDL) kolesterol merupakan hasil produksi kolesterol. HDL kolesterol mempunyai fungsi membersihkan pembuluh darah dari LDL kolesterol yang berlebihan, sedangkan LDL kolesterol jumlahnya berlebihan di dalam darah akan diendapkan pada dinding pembuluh darah dan membentuk bekuan yang dapat menyumbat pembuluh darah. Selain itu terdapat Trigliserida (TG) yang terbentuk sebagai hasil dari uraian tubuh pada makanan yang mengandung lemak dan juga berbentuk karbohidrat dan protein yang berlebihan yang tidak seluruhnya dibutuhkan sebagai sumber energi. Peningkatan atau penurunan profil lipid di atas hingga mencapai batas nilai normal merupakan pertanda terjadinya dislipidemia..$^{4,5}$

Kelainan metabolisme lipid disebut juga dislipidemia yang ditandai dengan peningkatan maupun penurunan profil lipid dalam plasma dan merupakan salah satu faktor risiko yang penting dalam terjadinya penyakit vaskular, termasuk aterosklerosis. Aterosklerosis mengakibatkan gangguan peredaran darah dan oksigen di dalam tubuh dan terjadi di dalam pembuluh arteri yang menuju ke otak maka bisa terjadi stroke. Penyebab terjadinya stroke iskemik adalah adanya kelainan profil lipid darah yang utama yaitu kenaikan kadar kolesterol total, trigliserida, LDL kolesterol serta penurunan kadar HDL kolesterol. Keempat profil lipid tersebut memiliki peranan yang penting dimana peningkatan trigliserida berakibat buruk pada pembuluh darah, peningkatan kolesterol berakibat penyumbatan pada pembuluh darah, peningkatan LDL berakibat pada penyempitan pembuluh darah serta penurunan HDL tidak dapat membersihkan pembuluh darah dari berbagai endapan yang disebabkan oleh ketiga profil lipid lainnya. Berdasarkan fenomena tesebut maka dalam penelitian ini perlu untuk mengetahui karakteristik kadar profil lipid pada penderita stroke iskemik. ${ }^{6}$

\section{Rumusan Masalah}

Berdasarkan latar belakang di atas, maka yang menjadi rumusan masalah dalam penelitian ini adalah "Bagaimanakah karakteristik kadar profil lipid pada penderita stroke iskemik di Rumah Sakit Ibnu Sina Makassar tahun 2017?"

\section{Tujuan Penelitian}

\subsection{Tujuan Umum}

Tujuan umum penelitian ini adalah untuk mengetahui karakteristik kadar profil lipid pada penderita stroke iskemik di Rumah Sakit Ibnu Sina Makassar tahun 2017. 


\subsection{Tujuan Khusus}

Adapun tujuan khusus dalam penelitian ini adalah

1. Mengetahui karakterisktik kadar kolesterol total pada penderita stroke iskemik di Rumah Sakit Ibnu Sina Makassar tahun 2017

2. Mengetahui karakteristik kadar kolesterol LDL pada penderita stroke iskemik di Rumah Sakit Ibnu Sina Makassar tahun 2017

3. Mengetahui karakterisktik kadar kolesterol HDL pada penderita stroke iskemik di Rumah Sakit Ibnu Sina Makassar tahun 2017

4. Mengetahui karakterisktik kadar kolesterol Trigliserida pada penderita stroke iskemik di Rumah Sakit Ibnu Sina Makassar tahun 2017

\section{Manfaat Penelitian}

\subsection{Bagi Peneliti}

Hasil penelitian ini dapat menambah pengetahuan peneliti khususnya mengenai karakteristik dari profil lipid pada penderita stroke iskemik selain itu hasil penelitian dapat dijadikan sebagai bahan rujukan bagi penelitian selanjutnya

\subsection{Bagi Institusi}

Sebagai sumbangan dalam mengkaji masalah profil lipid pada penderita stroke iskemik

\subsection{Bagi Masyarakat}

Sebagai bahan masukan untuk menambah wawasan dan pengetahuan

\section{Desain Penelitian}

Penelitian ini merupakan penelitian deskriptif untuk mengetahui karakteristik kadar profil lipid pada penderita stroke iskemik di Rumah Sakit Ibnu Sina Makassar pada tahun 2017. Pendekatan yang digunakan pada desain penelitian ini adalah cross sectional study, yaitu tiap subjek diobservasi satu kali dan pengukuran variabel subjek dilakukan pada saat pemeriksaan tersebut.

\section{Tempat dan Waktu Penelitian}

\section{a. Tempat}

Penelitian dilaksanakan di bagian Rekam Medik Rumah Sakit Ibnu Sina Makassar berdasarkan pertimbangan bahwa Rumah Sakit Ibnu Sina merupakan rumah sakit dibawah naungan Yayasan Wakaf UMI yang sudah meraih akreditasi paripurna

b. Waktu

Penelitian dilakukan di bulan Februari 2018

\section{Populasi, Sampel Penelitian}
a. Populasi

Populasi dalam penelitian ini adalah semua penderita stroke iskemik di Rumah Sakit Ibnu Sina Makassar pada tahun 2017

b. Sampel

Sampel dalam penelitian ini adalah semua populasi atau data pasien stroke yang memenuhi kriteria dijadikan sampel di Rumah Sakit Ibnu Sina Makassar sejak tahun 2017 yang memenuhi data lengkap

\section{Teknik Sampel}

Teknik pengambilan sampel adalah dengan menggunakan metode total sampling yaitu semua populasi yang memenuhi kriteria inklusi yang dijadikan sebagai sampel.

\section{Definisi Operasional dan Kriteria Objektif}

\section{Stroke Iskemik}

Stroke iskemik adalah tanda klinis disfungsi atau kerusakan jaringan otak yang disebabkan akibat kurangnya aliran darah ke otak sehingga mengganggu kebutuhan darah dan oksigen ke jaringan otak 
Kriteria Objektif :

Stroke Iskemik:

Diagnosis stroke iskemik yang ditegakkan oleh dokter penanggung jawab pasien melalui anamnesis, pemeriksaan fisis, dan pemeriksaan penunjang

2. Kadar profil lipid darah

Kadar profil lipid darah adalah kadar kolesterol total, LDL, HDL dan trigliserida pada pemeriksaan yang pertama kali pada saat pasien masuk rumah sakit dengan diagnosis stroke, yang merupakan hasil pemeriksaan Instalasi Laboratorium Patologi Klinik di Rumah Sakit Ibnu Sina Makassar

Kriteria Objektif :
a. Kolesterol Total $<200 \mathrm{mg} / \mathrm{dL} \quad$ : Normal $>200 \mathrm{mg} / \mathrm{dL} \quad$ : Tinggi
b. Kolesterol LDL $<130 \mathrm{mg} / \mathrm{dL} \quad$ : Normal $>130 \mathrm{mg} / \mathrm{dL} \quad:$ Tinggi
c. Kolesterol HDL $42-88 \mathrm{mg} / \mathrm{dL} \quad$ : Normal $<42 \mathrm{mg} / \mathrm{dL} \quad$ : Rendah
d. Trigliserida $<200 \mathrm{mg} / \mathrm{dL} \quad$ : Normal $>200 \mathrm{mg} / \mathrm{dL} \quad$ : Tinggi

\section{JENIS DATA DAN INSTRUMEN PENELITIAN}

1. Jenis Data Jenis data dalam penelitian ini adalah data sekunder yang diperoleh dari bagian rekam medik Rumah Sakit Ibnu Sina Makassar

2. Instrumen Penelitian Alat pengumpulan data dan instrumen penelitian yang dipergunakan adalah data-data yang didapatkan dari rekam medik

\section{Pengolahan dan Penyajian Data}

1. Pengolahan Data dan Analisa Data

Data yang dikumpulkan diolah dengan menggunakan program Microsoft Office Excel kemudian disajikan dalam bentuk tabel distribusi dan presentase secara deskriptif

2. Penyajian Data

Hasil penelitian ini disajikan dalam bentuk tabel dan grafik untuk menggambarkan karakteristik dari kolesterol total, LDL, HDL, dan trigliserida pada penderita stroke iskemik di Rumah Sakit Ibnu Sina Makassar

\section{Hasil Penelitian}

a. Kadar Kolesterol Total

Tabel 1: Distribusi Pasien Stroke Iskemik Berdasarkan Kadar Kolesterol Total pada Pasien yang Dirawat di Rumah Sakit Ibnu Sina Makassar pada Tahun 2017

\begin{tabular}{c|c|c}
\hline Kadar Kolesterol Total & Frekuensi (N) & Persentase (\%) \\
\hline Kolesterol Total Normal & 20 & $37 \%$ \\
Kolesterol Total Meningkat & 34 & $63 \%$ \\
\hline Total & 54 & 100 \\
\hline
\end{tabular}

Sumber : Data Rekam Medik Rumah Sakit Ibnu Sina Makassar Tahun 2017 
Ditinjau dari kadar kolesterol total maka dapat diperoleh tabel 1, bahwa peninggian kadar kolesterol total menempati jumlah tertinggi dari populasi yang telah didapatkan sebanyak $63 \%$, dan populasi dengan kolesterol total yang normal sebanyak $37 \%$.

b. Kadar Kolesterol LDL

Tabel 2: Distribusi Pasien Stroke Iskemik Berdasarkan Kadar Kolesterol LDL pada Pasien yang Dirawat di Rumah Sakit Ibnu Sina Makassar pada Tahun 2017

\begin{tabular}{c|c|c}
\hline Kadar Kolesterol LDL & Frekuensi (N) & Persentase (\%) \\
\hline Kolesterol LDL Normal & 23 & $43 \%$ \\
Kolesterol LDL Meningkat & 31 & $57 \%$ \\
\hline Total & 54 & 100 \\
\hline
\end{tabular}

Sumber : Data Rekam Medik Rumah Sakit Ibnu Sina Makassar Tahun 2017

Ditinjau dari kadar kolesterol LDL maka dapat diperoleh tabel 2, bahwa peninggian kadar kolesterol LDL menempati jumlah tertinggi dari populasi yang telah didapatkan sebanyak $57 \%$, dan populasi dengan kolesterol LDL yang normal sebanyak $43 \%$.

c. Kadar Kolesterol HDL

Tabel 3: Distribusi Pasien Stroke Iskemik Berdasarkan Kadar Kolesterol HDL pada Pasien yang Dirawat di Rumah Sakit Ibnu Sina Makassar pada Tahun 2017

\begin{tabular}{c|c|c}
\hline Kadar Kolesterol HDL & Frekuensi (N) & Persentase (\%) \\
\hline Kolesterol HDL Normal & 33 & $61 \%$ \\
Kolesterol HDL Rendah & 21 & $39 \%$ \\
\hline Total & 54 & 100 \\
\hline
\end{tabular}

Sumber : Data Rekam Medik Rumah Sakit Ibnu Sina Makassar Tahun 2017

Ditinjau dari kadar kolesterol HDL maka dapat diperoleh tabel 3, bahwa kadar kolesterol HDL yang normal menempati jumlah tertinggi dari populasi yang telah didapatkan sebanyak $61 \%$, dan populasi dengan kolesterol HDL yang rendah sebanyak $39 \%$.

d. Kadar Kolesterol Trigliserida

Tabel 4: Distribusi Pasien Stroke Iskemik Berdasarkan Kadar Kolesterol Trigliserida pada Pasien yang Dirawat di Rumah Sakit Ibnu Sina Makassar pada Tahun 2017

\begin{tabular}{l|c|c}
\hline Kadar Kolesterol Trigliserida & Frekuensi (N) & Persentase (\%) \\
\hline Trigliserida Normal & 36 & $67 \%$ \\
Trigliserida Meningkat & 18 & $33 \%$ \\
\hline \multicolumn{1}{c}{ Total } & 54 & 100 \\
\hline
\end{tabular}

Sumber : Data Rekam Medik Rumah Sakit Ibnu Sina Makassar Tahun 2017

Ditinjau dari kadar kolesterol trigliserida maka dapat diperoleh tabel 4 bahwa kadar kolesterol trigliserida yang normal menempati jumlah tertinggi dari populasi yang telah didapatkan sebanyak $67 \%$, dan populasi dengan kolesterol trigliserida yang rendah sebanyak $33 \%$. 
e. Distribusi Kadar Profil Lipid

Diagram 1: Distribusi Pasien Stroke Iskemik Berdasarkan Kadar Profil Lipid pada Pasien yang Dirawat di Rumah Sakit Ibnu Sina Makassar pada Tahun 2017

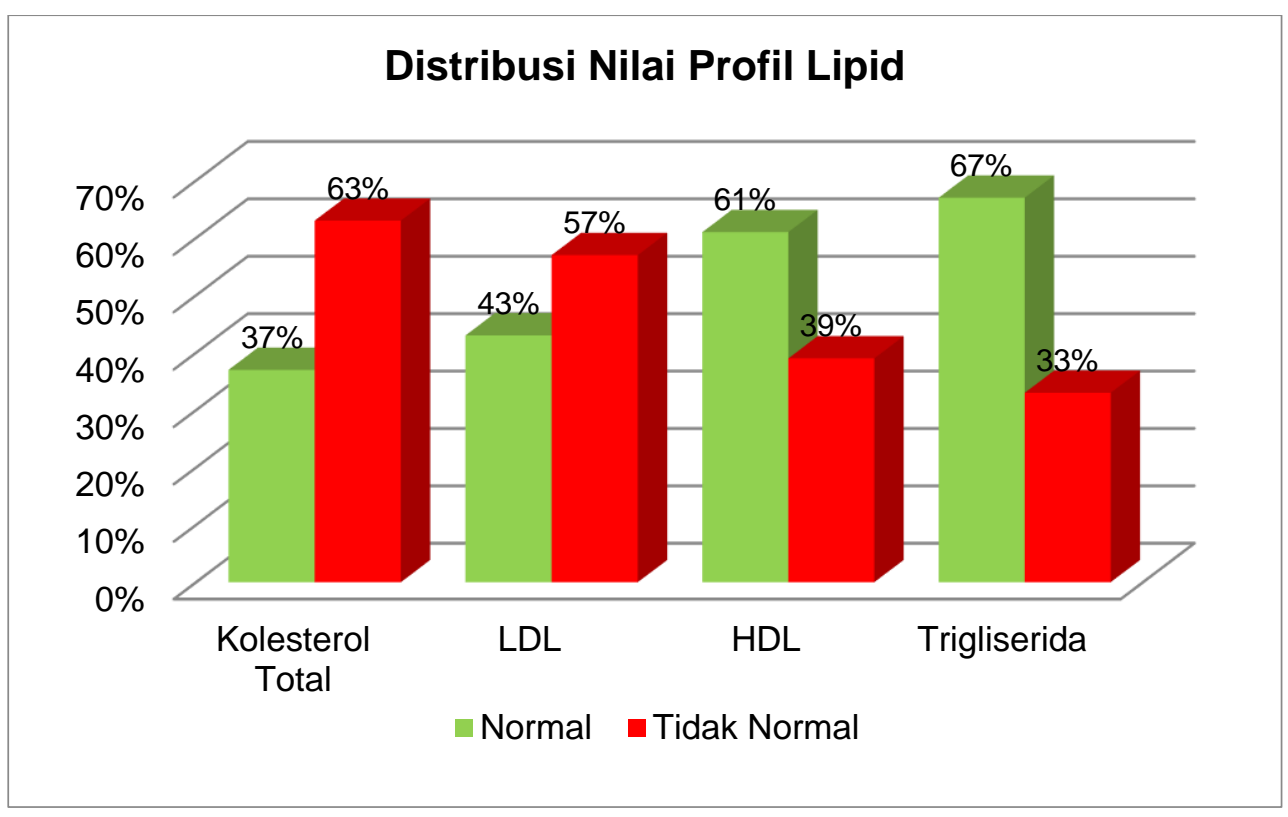

Ditinjau dari nilai kadar profil lipid dapat diperoleh dari diagram 1 di atas bahwa kadar kolesterol yang tidak normal yang menempati jumlah tertinggi yaitu kadar kolesterol total sebanyak $63 \%$, yang diikuti oleh kadar kolesterol LDL sebanyak $57 \%$, lalu kadar kolesterol HDL yang rendah sebanyak 39\%, dan kadar kolesterol trigliserida sebanyak 33\%. Sedangkan nilai kadar profil lipid yang normal dengan jumlah tertinggi pada kadar kolesterol trigliserida sebanyak $67 \%$, diikuti kadar kolesterol HDL yang normal sebanyak $61 \%$, lalu kadar kolesterol LDL yang normal sebanyak $43 \%$, dan kadar kolesterol total yang normal sebanyak $37 \%$.

\section{f. Distribusi Kadar Profil Lipid Berdasarkan Jenis Kelamin}

Diagram 2: Distribusi Pasien Stroke Iskemik Berdasarkan Kadar Profil Lipid Berdasarkan Jenis Kelamin pada Pasien yang Dirawat di Rumah Sakit Ibnu Sina Makassar pada Tahun 2017

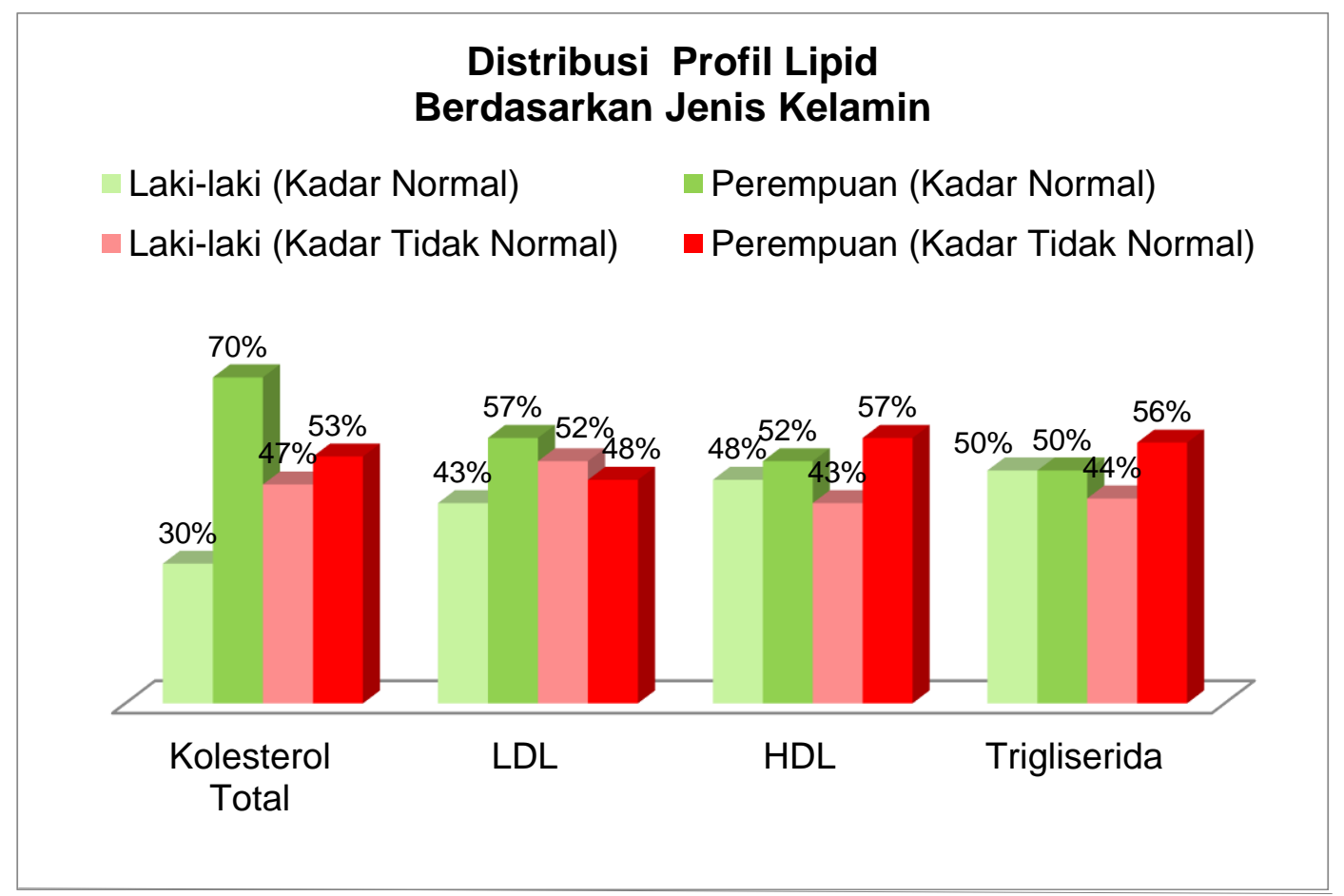


Ditinjau dari nilai kadar profil lipid normal berdasarkan jenis kelamin yang dapat diperoleh dari diagram 2 di atas didapatkan sebanyak $70 \%$ perempuan yang memiliki kadar kolesterol total normal dan hanya 30\% pada laki-laki. Diikuti oleh kadar kolesterol LDL normal pada perempuan sebanyak $57 \%$ dan pada laki-laki sebanyak $43 \%$. Selanjutnya pada kadar kolesterol HDL yang normal didapatkan sebanyak $52 \%$ pada perempuan dan hanya $48 \%$ pada laki-laki. Sedangkan pada kadar kolesterol trigliserida normal didapatkan pada perempuan dan laki-laki memiliki kadar kolesterol yang sebanding masing-masing sebanyak $50 \%$. Pada nilai kadar profil lipid yang tidak normal berdasarkan jenis kelamin yang didapatkan sebanyak 53\% perempuan yang memiliki kadar kolesterol total yang tidak normal dan hanya $47 \%$ pada laki-laki. Diikuti oleh kadar kolesterol LDL tidak normal pada laki-laki sebanyak $52 \%$ dan perempuan hanya sebanyak $48 \%$. Selanjutnya pada kadar kolesterol HDL yang tidak normal didapatkan sebanyak $57 \%$ pada perempuan dan hanya $43 \%$ pada laki-laki. Sedangkan pada kadar kolesterol trigliserida yang tidak normal sebanyak 56\% pada perempuan dan hanya $44 \%$ pada laki-laki.

\section{Pembahasan}

\section{Kolesterol Total}

Dari hasil penelitian ini didapatkan peninggian kadar kolesterol total menempati jumlah tertinggi dari populasi yang telah didapatkan sebanyak $63 \%$, dan populasi dengan kolesterol total yang normal sebanyak $37 \%$. Dari populasi jumlah sampel yang memiliki kadar kolesterol total yang tinggi didapatkan lebih banyak pada perempuan yaitu sebanyak $53 \%$, sedangkan pada laki-laki hanya 47\%. Hal ini sesuai dengan penelitian Tomita $\mathrm{H}$ (2011) yang menyatakan bahwa keluaran klinis dari pasien stroke iskemik berjenis kelamin perempuan lebih buruk dibandingkan dengan laki-laki yang diukur dengan menggunakan kuisioner yang berbeda yaitu Katz ADL Scale dan NIHSS. Pada penelitian tersebut disebutkan bahwa pasien stroke iskemik dengan jenis kelamin perempuan cenderung memiliki keluaran klinis yang lebih buruk. Selain itu, hormon juga diduga mempengaruhi keluaran klinis. Adanya perbedaan hormon seks antara laki-laki dan perempuan, dimana laki-laki didominasi oleh hormone seks testosteron, sedangkan pada wanita oleh estrogen. Dengan adanya efek vasoprotektif dari testosteron membuat keluaran klinis pada laki-laki lebih baik. Pada wanita, terutama yang sudah mengalami menopause, memiliki kadar estrogen yang sangat rendah, sehingga akan berdampak pada keluaran klinisnya. ${ }^{46,48,49,50}$

Perbedaan pada mikrovaskularisasi dan interaksi neuron di otak pada laki-laki dan perempuan diduga dapat menyebabkan respon yang berbeda terhadap adanya kerusakan pada otak, sehingga membuat keluaran klinis pada perempuan lebih buruk dibandingkan lakilaki. Menurut Roger VL (2012) yang menyatakan lebih banyak pada perempuan mengalami perubahan profil lipid sehingga dikaitkan dengan terjadinya insiden stroke iskemik. Hal ini diperkirakan karena pemakaian obat-obat kontrasepsi dan usia harapan hidup perempuan yang lebih tinggi dibandingkan dengan laki-laki. ${ }^{9,10,47}$

Kadar kolesterol total yang tinggi merupakan salah satu faktor risiko terjadinya stroke iskemik. Hal ini berkorelasi dengan penelitian Amna Siddique dkk. (2016) menyatakan bahwa hubungan antara kadar kolesterol total dan yang tinggi dengan penyakit jantung iskemik telah terbukti. Kadar kolesterol total yang tinggi diperkirakan menyebabkan 56\% penyakit jantung iskemik di seluruh dunia. Telah dilaporkan bahwa kolesterol total yang lebih tinggi pada fase akut stroke iskemik ternyata menjadi faktor prognostik yang untuk fungsi motorik jangka panjang.Hal ini berkaitan dengan peran kolesterol total dalam pembentukan plak aterosklerosis. Dalam Vytorin Efficacy International Trial yang terbaru didapatkan bahwa penurunan kadar kolesterol total berperan dalam menurunkan kejadian stroke. ${ }^{34,41}$

Pada penelitian yang dilakukan MRFIT (Multiple Risk Factor Intervention Trial) menunjukkan adanya hubungan antara kolesterol total yang tinggi dengan kejadian stroke iskemik. Bukti telah menunjukkan bahwa kadar kolesterol tinggi sangat meningkatkan risiko kematian akibat penyakit arteri koroner, infark miokard, pulmonal dan serebral. Saat ini direkomendasikan bahwa kadar kolesterol darah total sebaiknya kurang dari $200 \mathrm{mg} / \mathrm{dL}$. Selain itu, direkomendasikan bahwa kadar kolesterol LDL sebaiknya kurang dari $130 \mathrm{mg} / \mathrm{dL}$, kolesterol HDL sebaiknya lebih besar dari $40 \mathrm{mg} / \mathrm{dL}$ pada pria dan $50 \mathrm{mg} / \mathrm{dL}$ pada wanita, dan kadar trigliserida sebaiknya kurang dari $150 \mathrm{mg} / \mathrm{dL}^{335,36}$ 
Pada pasien stroke iskemik atau TIA yang disertai dengan peningkatan kadar kolesterol total, penyakit jantung koroner, ataupun sudah terbukti adanya plak aterosklerotik disarankan agar mengikuti program NCTEP III (National Cholesterol Education Program Adult Treatment Panel III) untuk modifikasi gaya hidup sehat, program diet, maupun dengan terapi obatobatan. Terapi dengan menggunakan statin dapat menurunkan insiden stroke yang telah dibuktikan oleh Meta-analysis Study pada 90.000 orang pasien stroke. Selain itu statin dapat mengurangi ketebalan tunika intima pada arteri carotis media. Pada tahun 2013 Meta-analysis Study mengemukakan bahwa terapi statin pada lebih dari 113.000 pasien dapat meningkatkan angka kelangsungan hidup pasien yang terdiagnosa stroke..$^{9,42}$

Penelitian menurut SPARCL (Stroke Prevention by Aggressive Reduction in Cholesterol Levels) terapi statin direkomendasikan untuk semua pasien stroke iskemik aterosklerotik atau TIA bahkan untuk mereka yang tidak memiliki penyakit jantung koroner agar dapat menurunkan risiko stroke dan insiden penyakit kardiovaskular. Efek pleiotropik statin yakni sebagai anti-inflamasi, peningkatan aktivitas fibrinolitik, peningkatan aliran darah serebral) juga sangat berpengaruh. Selain itu, manajemen dengan niacin atau gemfibrozil dapat dipertimbangkan untuk stroke iskemik atau pasien TIA dengan tingkat kadar kolesterol HDL yang rendah. 42

\section{Kolesterol LDL}

Dari hasil penelitian ini peninggian kadar kolesterol LDL menempati jumlah tertinggi dari populasi yang telah didapatkan sebanyak $57 \%$, dan populasi dengan kolesterol LDL yang normal sebanyak 43\%. Dari populasi jumlah sampel yang memiliki kadar LDL yang tinggi didapatkan lebih banyak pada laki-laki sebanyak $52 \%$ sedangkan pada perempuan hanya $48 \%$. Hal ini sesuai dengan Michael T,Murray dkk. (2013) yang mengatakan bahwa salah satu faktor risiko terjadinya peningkatan kadar kolesterol LDL dapat dipengaruhi oleh merokoknya seseorang. Pada yang sampel telah diteliti didapatkan pada laki-laki sebagian besar adalah perokok. 35

Menurut Murray, asap tembakau mengandung lebih dari 4000 bahan kimia, di mana lebih dari 50 zat telah diidentifikasi sebagai karsinogen. Zat kimia ini sangat merusak sistem kardiovaskular. Secara khusus, bahan kimia ini dibawa dalam aliran darah dan merusak lapisan arteri secara langsung. Selain itu, bahan kimia ini dapat merusak molekul dari kolesterol LDL yang mengakibatkan peningkatan kadar kolesterol LDL. Hal ini dapat memperburuk sistem kardiovaskular akibat racun rokok yang berhasil melewati arteri. Merokok berkontribusi terhadap kolesterol yang tinggi dengan merusak mekanisme umpan balik di hati yang mengontrol kolesterol yang diproduksi. Merokok juga meningkatkan agregasi trombosit dan peningkatan kadar fibrinogen, dua faktor risiko independen penting lainnya untuk CVD. dengan baik bahwa merokok adalah faktor yang berkontribusi terhadap tekanan darah tinggi. ${ }^{35}$

Telah diketahui bersama bahwa tingginya kadar kolesterol terutama kadar kolesterol LDL merupakan faktor risiko utama terjadinya aterosklerosis, dimana komplikasi utamanya adalah infark miokardial dan stroke iskemik. Kolesterol LDL merupakan pengangkut utama kolesterol pada manusia dan bertanggung jawab untuk memasok kolesterol ke seluruh jaringan tubuh untuk melengkapi kebutuhan jaringan yang membutuhkan kolesterol. Kolesterol LDL juga merupakan lipoprotein yang sudah sangat jelas terlibat dalam pembentukan formasi plak aterogenik. Tingkat sirkulasi LDL dapat ditingkatkan pada orang yang mengonsumsi lemak jenuh atau kolesterol dalam jumlah besar. Selain itu, kadar LDL juga meningkat pada orang yang memiliki cacat genetik yang dapat mempengaruhi fungsi reseptor LDL (hiperkolesterolemia familial, mutasi PCSK9, autosomal resesif hiperkolesterolemia) atau mutasi struktur apoprotein LDL, apo B, atau yang memiliki gangguan poligenik yang dapat mempengaruhi metabolisme LDL. Kolesterol LDL melintasi sel endotelium yang melapisi dinding arteri pada bagian tunika intima. Akibat densitasnya yang rendah, LDL dapat tersimpan pada tunika intima dan mengalami oksidasi atau modifikasi biokimia sehingga memicu datangnya makrofag. Hal ini dapat menstimulasi terjadinya proses aterogenesis. ${ }^{37,42}$

Pada penelitian inipun mendukung teori tersebut dimana pasien stroke iskemik dengan peningkatan kadar kolesterol LDL ditemukan lebih banyak dibanding yang memiliki kadar kolesterol LDL dengan nilai normal. 
Peningkatan kadar kolesterol total atau kolesterol LDL dan rendahnya kolesterol HDL adalah faktor risiko sederhana untuk terjadinya stroke. Sebuah metaanalisis uji coba statin menunjukkan bahwa semakin besar pengurangan kadar kolesterol LDL, semakin besar pengurangan risiko stroke. Oleh karena itu, AHA (American Heart Association) merekomendasikan terapi statin dengan efek penurun lipid intensif pada pasien dengan TIA yang memiliki bukti aterosklerosis dan kadar kolesterol LDL yang lebih tinggi dari $100 \mathrm{mg} / \mathrm{dL}$. Pada pasien dengan penyakit arteri koroner, hipertensi, diabetes dan yang memiliki risiko tinggi terhadap penyakit vaskular dengan terapi statin dapat menurunkan $17-21 \%$ risiko terjadi stroke. Teori ini telah dikonfirmasi oleh penelitian SPARCL (Stroke Prevention by Aggressive Reduction in Cholesterol Level). ${ }^{35,38}$

\section{Kolesterol HDL}

Kadar kolesterol HDL yang normal menempati jumlah tertinggi dari populasi yang telah didapatkan sebanyak $61 \%$, dan populasi dengan kolesterol HDL yang rendah sebanyak $39 \%$. Dari populasi jumlah sampel yang memiliki kadar HDL yang rendah didapatkan lebih banyak pada perempuan yaitu sebanyak $57 \%$, sedangkan pada laki-laki hanya sebanyak $43 \%$. Hal ini telah dijelaskan sebelumnya bahwa perempuan lebih banyak berisiko mengalami perubahan lipid akibat dari beberapa faktor yakni faktor hormonal, keluaran klinis yang buruk lebih banyak pada perempuan, penggunaan obat-obat kontrasepsi, serta harapan hidup perempuan yang lebih tinggi dibandingkan laki-laki. ${ }^{9,10}$

Kolesterol HDL merupakan satu-satunya lipoprotein anti-trombotik, sehingga kadar kolesterol HDL yang rendah dikaitkan sebagai faktor risiko terjadinya aterosklerosis pada stroke iskemik. Namun, stroke iskemik memiliki faktor risiko yang banyak (multifaktorial), yang tidak hanya terkait dengan aterosklerosis akibat kadar profil lipid yang abnormal. ${ }^{39,40}$

Menurut Lee YM dkk. (2011) yang menyatakan bahwa hipertensi merupakan faktor risiko utama untuk kedua jenis stroke yaitu stroke iskemik dan stroke hemoragik. Pada populasi umum, risiko stroke dua kali lipat untuk setiap $20 \mathrm{mmHg}$ peningkatan tekanan darah sistolik atau $10 \mathrm{mmHg}$ peningkatan tekanan darah diastolik. ${ }^{43}$

Diabetes mellitus meningkatkan risiko penyakit serebrovaskular iskemik yang diperkirakan dua sampai enam kali lipat dalam populasi umum. Selain itu, DM meningkatkan morbiditas dan mortalitas setelah stroke. Penyakit makrovaskuler adalah penyebab utama kematian di antara pasien dengan DM. Mekanisme stroke sekunder terhadap diabetes dapat disebabkan oleh aterosklerosis serebrovaskular, dan emboli jantung. Pada penderita diabetes mellitus memiliki risiko lebih besar mengidap penyakit arteri koroner. Peningkatan kolesterol LDL umumnya lebih banyak pada penderita DM. Selain itu struktur LDL pada penderita diabetes lebih kecil, lebih padat dan sangat mudah teroksidasi, sehingga dilihat dari sifatnya ini struktur LDL sangat berhubungan terhadap pembentukan aterogenesis. Demikian pula, merokok menyebabkan cedera endotel langsung, yang secara mandiri hampir melipatgandakan risiko stroke iskemik. Agregasi trombosit, deposisi lipid, dan pembentukan fibrin merupakan faktor penting dalam perkembangan aterosklerosis. $40,43,44,45$

Atrial Fibrilasi dikaitkan dengan risiko besar terjadinya stroke, gagal jantung, hipertensi, DM, stroke dengan riwayat TIA, dan pada usia yang lebih tua dari 75 tahun meningkatkan risiko terjadinya emboli. Selain itu, faktor risiko yang lain adalah pemakaian obat kontrasepsi. Analisis stratifikasi pada pemakai kontrasepsi oral terutama teramati pada wanita diatas 35 tahun, perokok, hipertensi, diabetes, menderita migren, serta wanita dengan riwayat penyakit tromboembolik menunjukkan peningkatan insiden stroke. ${ }^{10,44}$

Obesitas, khususnya pada obesitas sentral pada perut, merupakan faktor risiko penting untuk penyakit kardiovaskular pada laki-laki maupun perempuan dari segala usia. Ada beberapa bukti menunjukkan bahwa aktivitas fisik dapat mengurangi risiko stroke. Olahraga teratur menurunkan tekanan darah arteri dan dapat menurunkan resistensi insulin sehingga morbiditas dan mortalitas kardiovaskular yang lebih rendah. ${ }^{44}$

Adanya kadar kolesterol HDL normal yang lebih banyak ditemukan pada populasi penelitian ini, dapat dikarenakan patogenesis stroke iskemik yang terjadi akibat faktor-faktor risiko yang lain. 
Pada penelitian ini, kadar kolesterol trigliserida yang normal menempati jumlah tertinggi dari populasi yang telah didapatkan sebanyak 67\%, dan populasi dengan kolesterol trigliserida yang rendah sebanyak 33\%. Dari populasi jumlah sampel yang memiliki kadar kolesterol trigliserida yang tinggi didapatkan lebih banyak pada perempuan yaitu sebanyak $56 \%$, sedangkan pada laki-laki hanya sebanyak $44 \%$. Hal ini telah dijelaskan sebelumnya bahwa perempuan lebih banyak berisiko mengalami perubahan lipid akibat dari beberapa faktor yakni faktor hormonal, keluaran klinis yang buruk lebih banyak pada perempuan, penggunaan obatobat kontrasepsi, serta harapan hidup perempuan yang lebih tinggi dibandingkan laki-laki. ${ }^{9,10}$

Analisis multivariat dengan data selama 8 tahun The Large-scale Prospective Cardiovaskular Munster Study menemukan hipertrigliserida menjadi faktor risiko independen untuk kejadian penyakit jantung setelah mengendalikan kadar kolesterol LDL dan kolesterol HDL. Hipertrigliserida yang dikombinasikan dengan peningkatan kadar kolesterol LDL dan rasio yang tinggi antara kolesterol LDL dan HDL (LDL:HDL >5) meningkatkan risiko untuk peristiwa PJK sekitar enam kali lipat. ${ }^{36}$

Daniel dkk. (2014) dalam penelitiannya terkait profil lipid pada pasien stroke juga menemukan korelasi antara hipertrigliserida dengan peningkatan risiko penyakit kardiovaskular, terutama pada kadar kolesterol HDL yang rendah dan kadar kolesterol LDL tinggi dan mungkin menjadi faktor risiko independen untuk kejadian stroke iskemik. ${ }^{41}$

Namun dalam penelitian ini didapatkan pasien stroke iskemik yang memiliki kadar trigliserida normal dengan presentasi yang lebih banyak daripada yang mengalami peningkatan kadar trigliserida. Hal ini juga dapat dikaitkan dengan faktor risiko pada stroke iskemik yang multifaktorial.

Menurut Emer McGrath dkk. (2018) mengemukakan bahwa stroke iskemik maupun hemoragik dikaitkan dengan sejumlah faktor risiko yang dapat dimodifikasi yakni hipertensi, diabetes mellitus, merokok, pola makan yang buruk, dan aktivitas fisik. Interstroke Study mengemukakan bahwa tedapat 26.919 orang dari 32 negara yang melaporkan bahwa terdapat 8 faktor risiko utama dimana 90\% dari Populasi-Attributable Risk (PAR) terdapat pada penderita stroke iskemik yaitu hipertensi, merokok, diet, tingkat aktivitas fisik, diabetes mellitus, asupan alkohol, stress/depresi psikososial, fibrilasi atrium. Dari faktor-faktor risiko ini, terdapat lima terkait dengan $80 \%$ PAR untuk semua jenis stroke yakni hipertensi, merokok, obesitas perut, aktivitas fisik, dan diet. Jadi sebagian besar stroke berpotensi dapat dicegah melalui intervensi yang bertujuan untuk memodifikasi faktor risiko. Hipertensi merupakan faktor risiko terkuat untuk kedua jenis stroke yakni stroke iskemik dan stroke hemoragik. Modifikasi gaya hidup dengan mengurangi asupan garam dan penggunaan obat-obatan anti hipertensi mungkin diperlukan. Pengobatan hipertensi dan menurunkan insiden stroke hingga $40 \%{ }^{1,43}$

Faktor risiko lain yang dapat mempengaruhi terjadinya stroke iskemik selain profil lipid yang tidak normal adalah merokok. Merokok merupakan termasuk dalam faktor risiko utama untuk penyakit arteri koroner, stroke, dan penyakit arteri perifer. Risiko stroke pada perokok adalah dua hingga tiga kali lebih besar daripada bukan perokok. Mekanisme aterogenesis pada rokok yaitu dengan mengurangi kapasitas darah untuk mengantarkan oksigen. Selain itu dapat terjadi meningkatkan koagulasi dari darah dan memicu trombosis arteri. Kandungan tembakau pada rokok dapat meningkatkan ketebalan plak arteri karotis. Sementara infark miokard hampir selalu mengikuti penyakit aterotrombosis, infark otak akibat penyakit jantung rematik, dan penyakit stenosis karotis akibat aterosklerosis. ${ }^{35,44}$

\section{Kesimpulan}

Dari jumlah total sampel sebanyak 54 orang didapatkan:

1. Sebanyak 34 orang (63\%) dari jumlah sampel mengalami peningkatan kadar kolesterol total dan 20 orang (37\%) dalam batas normal

2. Sebanyak 31 orang (57\%) dari jumlah sampel mengalami peningkatan kadar LDL dan 23 orang (43\%) dalam batas normal

3. Sebanyak 21 orang (39\%) dari jumlah sampel mengalami penurunan kadar HDL dan 33 orang $(61 \%)$ dalam batas normal

4. Sebanyak 18 orang (33\%) dari jumlah sampel mengalami peningkatan kadar trigliserida dan 36 orang $(67 \%)$ dalam batas normal 


\section{Saran}

1. Perlunya tenaga kesehatan meningkatkan promosi kesehatan bagi masyarakat serta menganjuran untuk memeriksakan kadar profil lipid secara berkala dalam rangka menurunkan insiden stroke

2. Perlunya masyarakat menerapkan perilaku hidup sehat dalam kehidupan sehari-hari

3. Perlunya dilakukan pengobatan yang teratur pada faktor risiko hiperlipidemia oleh tenaga kesehatan untuk menurunkan insiden stroke

4. Perlu dilakukan penelitian lebih lanjut mengenai karakteristik profil lipid pada penderita stroke dengan jumlah sampel yang lebih besar sehingga akan memberikan hasil lebih akurat

\section{DAFTAR PUSTAKA}

1. Mcgrath E, Canavan M, Donnell MO. Chapter 145 - Stroke.Seventh Edition. Hematology. Elsevier Inc.; 2018. 2133-2141 p.

2. Dewanto,George dkk. 2009. Panduan Praktis Diagnosis dan Tatalaksana Penyakit Saraf, Cetakan 1. Hal 24-25. Jakarta: EGC

3. Sutrisno, Alfred Dr. 2007. Stroke You Must Know Before You Get It. Sebaiknya Anda Tahu Sebelum Anda Terserang Stroke. Jakarta : EGC

4. Botham, K.M., Mayes, P.A., 2012. Harper's Illustrated Biochemistry: Cholesterol Synthesis, Transpor \& Excretion. Amerika Serikat: McGraw Hill

5. Yovana,S. 2012. Hubungan profil lipid darah pada penderita stroke iskemik. Jurnal Kedokteran Fakultas Kedokteran Univesitas Muhammadiyah Semarang

6. Afiliasi, 2008. Dislipidemia. Jurnal Kedokteran Universitas Muhammadiyah Semarang

7. Alqoriah,R.2011. Hubungan Jumlah Leukosit Darah Pada Penderita Stroke Iskemik Akut di RSUP. H. Adam Malik Medan Tahun 2010. Fakultas Kedokteran Universitas Sumatera Utara

8. Jauch, E.C., Stettler, B., Arnold, J.L., et al., 2015. Ischemic Stroke.

9. Rockman CB, Maldonado TS, Mackey WC. Cerebrovaskular Disease: General Considerations Based on a chapter in the seventh edition [Internet]. Eighth Edition. Vol. 16, Rutherford's Vaskular Surgery, 2-Volume Set, 8/e. Elsevier Inc.; 2014. 1456-1472.e4 p.

10. Goldstein LB, Adams R, Alberts MJ, Appel LJ, Brass LM, Bushnell CD, Culebras A, DeGraba TJ, Gorelick PB, Guyton JR, Hart RG, Howard G, Kelly-Hayes M, Nixon JV, Sacco RL. Premiary Prevention Of Stroke, AHA/ASA Guideline, 2006.

11. Patricia,Heidi dkk. 2015. Karakteristik penderita stroke yang dirawat inap di RSUP.Prof.Dr.R.D.Kondou Manado. Bagian Neurologi Fakultas Kedokteran Universitas Sam Ratulangi Manado

12. Tjondro,D.2012. Hubungan profil lipid darah pada penderita stroke iskemik. Fakultas Kedokteran Universitas Muhammadiyah Sermarang.

13.S,Ramadhani. 2012. Stroke Iskemik. Fakultas Kedokteran Universitas Muhammadiyah Semarang.

14. Price, Sylvia Anderson. 2008. Patofisiologi Konsep Klinis Proses-Proses Penyakit: Pathophysiology Clinical Concept Of Disease Processes. Alih Bahasa: Peter Anugrah. Edisi:4. Jakarta: EGC

15. Wardaini, Leny. 2012. Hubungan Trigliserida Tidak Puasa Dengan Kejadianstroke Iskemik. Spesialis IImu Penyakit Saraf:Fakultas Kedokteran Universitas Sumatera Utara

16.Wijaya Kristianto, Aji. Patofisiologi Stroke Non Hemoragik Akibat Trombus. Fakultas Kedokteran Universitas Udayana: Bagian IImu Penyakit Saraf RS Sanglah Denpasar

17. Goetz Christopher G. 2007.Cerebrovaskular Diseases. In : Goetz: Textbook of Clinical Neurology, 3rd ed. Philadelphia : Saunders

18. Rahajuningsih.2009. Diagnosis Stroke. Fakultas Kedokteran Universitas Lampung.

19. Stanley J. Swierzewski, Stroke, 2008.

20. Notosiswoyo. Diagnosis Stroke. Fakultas Kedokteran Universitas Lampung.

21. Arifputera Andy, dkk. Stroke Kapita Selekta Kedokteran Essential Medicine, edisi:IV, Jilid II.2014.Jakarta:Media Aeusculapius

22. Beny,S.Alexander. 2013. Profil Lipid. Jurnal Fakultas Kedokteran Universitas Diponegoro hal 6-7. 
23. Hasibuan, Analisa Kadar Lipid Profil Pada Darah Secara Spektrofotometer Microlab 300, Fakultas kedokteran Universitas Sumatera utara, 2011,

24. Kurniawati, Inge. Lipid, Fungsi dan Jenisnya. 2014. Fakultas Kedokteran Universitas Diponegoro

25. Arifnaldi,SM.2014. Hubungan Kadar Trigliserida Terhadap Stroke Iskemik di RSD Sukoharjo. Fakultas Kedokteran Universitas Muhammiyah Surakarta.

26. Adam John MF . Dislipidemia .Dalam : Sudoyo Aru W, Setiyohadi Bambang ,Alwi Idrus dkk. 2014Buku Ajar IImu Penyakit Dalam Jilid III, Edisi IV, Jakarta:FK-UI

27. Yates A. John, Defranzo Ralph A. Kelainan Metabolisme.Dalam Stein Jay H. Paduan Klinik IImu Penyakit Dalam . Edisi ketiga Jakarta: EGC. Hal:660

28. Goldberg J.Diabetik Dyslipidemia : Cause and Consequenses, ,Clinical Review. The journal of clinical Endocrinologi \& Metabolism

29. Harefa K, Pengaruh Aktifitas Fisik Dan Ekstrak Teh Hijau (Camellia Sinensis) Terhadap Profil Lipid Mencit Jantan (Mus Musculus) Strain Dd Webster Dengan Pakan Tinggi Lemak, Fakultas kedokteran Universitas Sumatera utara 2011

30. Yuenirwati,Yuyun. 2015. Deteksi Dini Strokelskemik Dengan Pemeriksaan Ultrasonografi Vaskular dan Variasi Genetik. Cetakan 1. Malang: Universitas Brawijaya Press (UB Press). Halaman:94-96

31. Lily L. Rilantono. Rahasia Penyakit Kardiovaskular (PKV). Fakultas Kedokteran UI. Halaman 127-130.

32. Prasetyo, Aspek Seluler Dan Molekuler Aterosklerosis, 2006 Ginsberg,Lionel.2010. Lecture Notes:Neurology, $9^{\text {th }}$ edition. University Collage London Medical School:Londons

33. Reduction I, Ef V, Trial I. Cholesterol-lowering interventions and stroke: Insights from IMPROVE-IT. 2018;248(2016):2016-8.

34. Collaboration PS, Collaboration PS, Mrfit T. Comment The paradox of cholesterol and stroke. 2018;370.

35. Murray MT. Atherosclerosis. Elsevier Inc:2018. Chapter 148. Page 1225-1227

36. Beltowski J. Reverse epidemiology in ischemic stroke: high cholesterol as a predictor of improved survival in stroke patients Clinical Lipidology Reverse epidemiology in ischemic stroke: high cholesterol as a predictor of improved. 2017;4299.

37. Souter MJ, Lam AM. Neurocritical Care. Elsevier Inc:2018

38. Sciences A. Pattern of dyslipidemia in ischemic stroke. 2015;5(2):26-9.

39. Crocco TJ, Meurer WJ. Stroke. Ninth Edition. Rosen's Emergency Medicine. Elsevier Inc.; 1241-1255.e3 p.

40. Radeva N. Lipid Profile In Ischemic Stroke Patient. 2014;IV(1):2012-5

41. Siddique A, Bukhari H, Shoukat A, Mahmood Z, Ahmad N. Correlation between Acute Ischemic Stroke, Higher Total Cholesterol Level and High Barthel Index Score. 2016;125-30.

42. Kivipelto M, Hooshmand B, Solomon A. Chapter 11 - Cardiovaskular Disease, Stroke, and Dementia. 3rd ed. Cardiology. Elsevier Ltd.; 2010. 135-153 p

43. Lee YM, Magarik JA. Acute Medical Management of Ischemic and Hemorrhagic Stroke Descargar PDF Pathophysiology of Ischemic Stroke. Seventh Edition. Youmans and Winn Neurological Surgery, 4-Volume Set. Elsevier Inc.; 2011. 3040-3045.e1

44. Biller, J., Ruland, S., \& Schneck M. Ischemic Cerebrovaskular Disease. Bradley's Neurol Clin Pract. 2016;920-67.

45. Freeman MW, Walford GA. Lipoprotein Metabolism and the Treatment of Lipid Disorders. Seventh Edition. Endocrinology: Adult and Pediatric. Elsevier; 2016. 715-736.e7.

46. Tomita H, Hagii J, Metoki N, Saito S, Shiroto H, Hitomi H, et al. Impact of Sex Difference on Severity and Functional Outcome in Patients with Cardioembolic Stroke. J Stroke Cerebrovasc Dis. 2015;24(11):2613-8.

47. Ikeda T, Aoyagi O. Relationships between Gender Difference in Motor Performance and Age , Movement Skills and Physical Fitness among 3- to 6-year-old Japanese Children based on Effect Size Calculated by Meta-analysis. Growth Dev. 2009;5:9-23.

48. Royen A. Perbedaan Hormon antara Pria dan Wanita. 2015

49. De Lacalle S. Estrogen effects on neuronal morphology. Endocrine. 2006;29(2):185-90.

50. Hess $\mathrm{R}$ a. Estrogen in the adult male reproductive tract: a review. Reproduction Bio Endocrinol. 2003;1:52. 


\section{Lampiran 01 :}

DATA REKAM MEDIK

\begin{tabular}{|c|c|c|c|c|c|c|c|c|c|c|c|}
\hline No & Nama & Umur & JK & $\begin{array}{c}\text { Faktor } \\
\text { Keturung } \\
\text { n }\end{array}$ & CT Scan & $\begin{array}{l}\text { Penlyakit } \\
\text { Jantung }\end{array}$ & $\begin{array}{l}\text { Rperten } \\
\text { sil } \\
\text { Disbetes } \\
\text { Mellitus } \\
\text {. }\end{array}$ & $\begin{array}{c}\text { Hiperkolestero } \\
1\end{array}$ & Obesitas & $\begin{array}{l}\text { Alkohol' } \\
\text { Kons umsi } \\
\text { Obat- } \\
\text { Obata nl } \\
\text { Merokok }\end{array}$ & $\begin{array}{l}\text { Pemakaian } \\
\text { Kontrasepsi } \\
\text {. }\end{array}$ \\
\hline 1 & Ny $S$ & 42 & 9 & $\begin{array}{c}\text { Tidak } \\
\text { diketah ui }\end{array}$ & $\begin{array}{c}\text { Infark luas } \\
\text { Cerebri } \\
\text { Dextra }\end{array}$ & $\begin{array}{l}\text { Tidak } \\
\text { diketah ui }\end{array}$ & $\underset{\mathrm{HT}}{\mathrm{DM}}$ & $\sqrt{ }$ & $\checkmark$ & - & $\begin{array}{c}\text { Tidsk } \\
\text { diketah ui }\end{array}$ \\
\hline 2 & $\mathrm{Ng} M$ & 51 & $?$ & $\begin{array}{c}\text { Tidak } \\
\text { diketah ui }\end{array}$ & NHS & $\begin{array}{l}\text { Tidak } \\
\text { diketah ui }\end{array}$ & $\begin{array}{l}\mathrm{HT} \\
\mathrm{DM}\end{array}$ & Normal & $\sqrt{ }$ & - & $\begin{array}{l}\text { Tidak } \\
\text { diketah ui }\end{array}$ \\
\hline 3 & Tn.A & 59 & 2 & $\begin{array}{c}\text { Tidak } \\
\text { diketah ui }\end{array}$ & NHS & $\begin{array}{l}\text { Tidsk } \\
\text { diketah ui }\end{array}$ & $\begin{array}{l}\mathrm{HT} \\
\mathrm{DM}\end{array}$ & Normal & - & Merokok & $\begin{array}{l}\text { Tidsk } \\
\text { diketah ui }\end{array}$ \\
\hline 4 & Ny.I & 44 & 9 & $\begin{array}{c}\text { Tidak } \\
\text { diketah ui }\end{array}$ & NHS & $\begin{array}{l}\text { Tidak } \\
\text { diketah ui }\end{array}$ & HT & Normal & - & - & $\begin{array}{c}\text { Tidak } \\
\text { diketah ui }\end{array}$ \\
\hline 5 & $\mathrm{Ny} D$ & 43 & 9 & $\begin{array}{c}\text { Tidak } \\
\text { diketah ui }\end{array}$ & NHS & $\begin{array}{c}\text { Tidak } \\
\text { diketah ui }\end{array}$ & $\begin{array}{l}\mathrm{DM} \\
\mathrm{HT}\end{array}$ & $\sqrt{ }$ & $\checkmark$ & - & $\begin{array}{l}\text { Tidak } \\
\text { diketah ui }\end{array}$ \\
\hline 6 & $N_{f} A$ & 61 & 9 & $\begin{array}{c}\text { Tidak } \\
\text { diketah ui }\end{array}$ & $\begin{array}{c}\text { NHS } \\
\& \mathrm{Ca} \\
\text { Ovarium }\end{array}$ & $\begin{array}{l}\text { Tidak } \\
\text { diketah ui }\end{array}$ & $\begin{array}{l}\mathrm{HT} \\
\mathrm{DM}\end{array}$ & $\checkmark$ & Normal & - & $\begin{array}{l}\text { Tidak } \\
\text { diketah ui }\end{array}$ \\
\hline 7 & Tn.A & 61 & 2 & $\begin{array}{c}\text { Tidsk } \\
\text { diketah ui }\end{array}$ & NHS & $\begin{array}{l}\text { Tidak } \\
\text { diketah ui }\end{array}$ & $\begin{array}{l}\mathrm{HT} \\
\mathrm{DM}\end{array}$ & $\sqrt{ }$ & $\sqrt{ }$ & Merokok & $\begin{array}{l}\text { Tidak } \\
\text { diketah ui }\end{array}$ \\
\hline 8 & $\mathrm{Ny} N$ & 78 & $\cong$ & $\begin{array}{c}\text { Tidak } \\
\text { diketah ui } \\
\end{array}$ & NHS & $\begin{array}{c}\text { Tidak } \\
\text { diketah ui }\end{array}$ & HT & Normal & - & - & $\begin{array}{c}\text { Tidak } \\
\text { diketah ui }\end{array}$ \\
\hline 9 & $\mathrm{Ny} S \mathrm{~S}$ & 44 & $?$ & $\begin{array}{c}\text { Tidak } \\
\text { diketah ui }\end{array}$ & NAS & $\begin{array}{c}\text { Tidak } \\
\text { diketah ui }\end{array}$ & HT & $\sqrt{ }$ & $\sqrt{ }$ & - & $\begin{array}{c}\text { Tidak } \\
\text { diketah ui }\end{array}$ \\
\hline 10 & Tn.H & 34 & 2 & $\begin{array}{c}\text { Tidak } \\
\text { diketah ui }\end{array}$ & $\begin{array}{c}\text { In'iark } \\
\text { Cerebri }\end{array}$ & $\begin{array}{c}\text { Tidak } \\
\text { diketah ui }\end{array}$ & $\begin{array}{l}\text { HT } \\
\text { DM }\end{array}$ & $\sqrt{ }$ & $\cdot$ & Merokok & $\begin{array}{c}\text { Tidak } \\
\text { diketah ui }\end{array}$ \\
\hline 11 & Ny.H & 47 & $?$ & $\begin{array}{c}\text { Tidak } \\
\text { diketah ui }\end{array}$ & NHS & $\begin{array}{c}\text { Tidak } \\
\text { diketah ui }\end{array}$ & DM & $\sqrt{ }$ & $\cdot$ & $\cdot$ & $\begin{array}{c}\text { Tidak } \\
\text { diketah ui }\end{array}$ \\
\hline 12 & Tn.A & 63 & 2 & $\begin{array}{c}\text { Tidak } \\
\text { diketah ui }\end{array}$ & $\begin{array}{l}\text { Oklusi A. } \\
\text { Cerebri } \\
\text { Medis }\end{array}$ & $\begin{array}{c}\text { Tidak } \\
\text { diketah ui }\end{array}$ & $\begin{array}{l}\text { HT } \\
\text { DM }\end{array}$ & Normal & $69 \mathrm{~kg}$ & Merokok & $\begin{array}{c}\text { Tidak } \\
\text { diketah ui }\end{array}$ \\
\hline 13 & $\operatorname{Tn} . A$ & 75 & 2 & $\begin{array}{c}\text { Tidak } \\
\text { diketah ui }\end{array}$ & NHS & $\begin{array}{c}\text { Tidak } \\
\text { diketah ui }\end{array}$ & $\begin{array}{l}\text { HT } \\
\text { DM }\end{array}$ & Normal & $\cdot$ & Merokok & $\begin{array}{c}\text { Tidak } \\
\text { diketah ui }\end{array}$ \\
\hline 14 & $\operatorname{Tn} \mathrm{N}$ & 72 & 2 & $\begin{array}{c}\text { Tidak } \\
\text { diketah ui }\end{array}$ & Normal & $\begin{array}{c}\text { Tidak } \\
\text { diketah ui }\end{array}$ & HT & Normal & $\cdot$ & $\cdot$ & $\begin{array}{c}\text { Tidak } \\
\text { diketah ui }\end{array}$ \\
\hline 15 & $\mathrm{~N}_{f} \mathrm{~S}$ & 35 & $?$ & $\begin{array}{c}\text { Tidak } \\
\text { diketah ui }\end{array}$ & N-S & $\begin{array}{c}\text { Tidak } \\
\text { diketah ui }\end{array}$ & $\begin{array}{l}\text { HT } \\
\text { DM }\end{array}$ & Normal & $\cdot$ & $\cdot$ & $\begin{array}{c}\text { Tidak } \\
\text { diketah ui }\end{array}$ \\
\hline 16 & Ny.R & 635 & $?$ & $\begin{array}{c}\text { Tidak } \\
\text { diketah ui }\end{array}$ & NAS & $\begin{array}{c}\text { Tidak } \\
\text { diketah ui }\end{array}$ & $\begin{array}{l}\text { HT } \\
\text { DM }\end{array}$ & $\sqrt{ }$ & $\sqrt{ }$ & $\cdot$ & $\begin{array}{c}\text { Tidak } \\
\text { diketah ui }\end{array}$ \\
\hline
\end{tabular}




\begin{tabular}{|c|c|c|c|c|c|c|c|c|c|c|c|}
\hline 17 & Ny. N & 55 & 9 & $\begin{array}{c}\text { Tidak } \\
\text { diketahui }\end{array}$ & NHS & $\begin{array}{c}\text { Tidak } \\
\text { diketah ui }\end{array}$ & HT & $\sqrt{ }$ & BB:54 & $\cdot$ & $\begin{array}{c}\text { Tidak } \\
\text { diketah u }\end{array}$ \\
\hline 18 & Tn.R & 68 & 2 & $\begin{array}{l}\text { Tidak } \\
\text { diketahui }\end{array}$ & NHS & $\begin{array}{c}\text { Tidak } \\
\text { diketah ui }\end{array}$ & $\begin{array}{l}\mathrm{HT} \\
\mathrm{DM}\end{array}$ & $\sqrt{ }$ & BB:56 & Merokok & $\begin{array}{c}\text { Tidak } \\
\text { diketah ui }\end{array}$ \\
\hline 19 & $\operatorname{Tn} . M$ & 74 & 2 & $\begin{array}{c}\text { Tidak } \\
\text { diketahui }\end{array}$ & $\begin{array}{l}\text { Infark } \\
\text { Cerebri } \\
\text { Sinistra }\end{array}$ & $\begin{array}{c}\text { Tidak } \\
\text { diketah ui }\end{array}$ & $\begin{array}{l}\mathrm{HT} \\
\mathrm{DM}\end{array}$ & $\sqrt{ }$ & - & Merokok & $\begin{array}{c}\text { Tidak } \\
\text { diketah ui }\end{array}$ \\
\hline 20 & Tn.Z & 67 & 2 & $\begin{array}{l}\text { Tidak } \\
\text { diketahui }\end{array}$ & NHS & $\begin{array}{c}\text { Tidak } \\
\text { diketah ui }\end{array}$ & $\begin{array}{l}\mathrm{HT} \\
\mathrm{DM}\end{array}$ & $\sqrt{ }$ & - & Merokok & $\begin{array}{l}\text { Tidak } \\
\text { diketah ui }\end{array}$ \\
\hline 21 & TnE & 57 & 2 & $\begin{array}{l}\text { Tidak } \\
\text { diketahui }\end{array}$ & NHS & $\begin{array}{c}\text { Tidak } \\
\text { diketah ui }\end{array}$ & $\begin{array}{l}\text { HT } \\
\text { DM }\end{array}$ & $\sqrt{ }$ & $\sqrt{ }$ & $\begin{array}{l}\text { Merokok } \\
\text { Alkohol }\end{array}$ & $\begin{array}{c}\text { Tidak } \\
\text { diketah u }\end{array}$ \\
\hline 22 & Ny.H & 41 & 9 & $\begin{array}{c}\text { Tidak } \\
\text { diketahui }\end{array}$ & N-S & $\begin{array}{c}\text { Tidak } \\
\text { diketah ui }\end{array}$ & DM & Normal & $\sqrt{ }$ & $\cdot$ & $\begin{array}{c}\text { Tidak } \\
\text { diketah u }\end{array}$ \\
\hline 23 & $\operatorname{Tn} B$ & 62 & 2 & $\begin{array}{l}\text { Tidak } \\
\text { diketahui }\end{array}$ & NHS & $\begin{array}{c}\text { Tidak } \\
\text { diketah ui }\end{array}$ & HT & Normal & - & $\begin{array}{l}\text { Merokok } \\
\text { Alkohol }\end{array}$ & $\begin{array}{c}\text { Tidak } \\
\text { diketah ui }\end{array}$ \\
\hline 24 & Tn.R & 35 & 2 & $\begin{array}{c}\text { Tidak } \\
\text { diketahui }\end{array}$ & NHS & $\begin{array}{c}\text { Tidak } \\
\text { diketah ui }\end{array}$ & HT & $\sqrt{ }$ & $60 \mathrm{~kg}$ & & $\begin{array}{c}\text { Tidak } \\
\text { diketah u }\end{array}$ \\
\hline
\end{tabular}

\begin{tabular}{|c|c|c|c|c|c|c|c|c|c|c|c|}
\hline 25 & Tn.M & 49 & 2 & $\begin{array}{c}\text { Tidak } \\
\text { diketahui }\end{array}$ & NHS & $\begin{array}{c}\text { Tidak } \\
\text { diketah ui }\end{array}$ & $\begin{array}{c}\mathrm{DM} \\
\mathrm{HT}\end{array}$ & $v$ & $\cdot$ & Merokok & $\begin{array}{c}\text { Tidak } \\
\text { diketah u }\end{array}$ \\
\hline 26 & $\mathrm{Ng} H$ & 61 & 9 & $\begin{array}{c}\text { Tidak } \\
\text { diketahui }\end{array}$ & $\begin{array}{c}\text { In'ark } \\
\text { Cerebri }\end{array}$ & $\begin{array}{c}\text { Tidak } \\
\text { diketah ui }\end{array}$ & HT & $\sqrt{1}$ & $\sqrt{ }$ & $\cdot$ & $\begin{array}{c}\text { Tidak } \\
\text { diketah u }\end{array}$ \\
\hline 27 & $\mathrm{Ny} S \mathrm{~S}$ & 55 & 9 & $\begin{array}{c}\text { Tidak } \\
\text { diketahui }\end{array}$ & $\begin{array}{c}\text { Infark } \\
\text { Cerebri }\end{array}$ & $\begin{array}{c}\text { Tidak } \\
\text { diketah ui }\end{array}$ & $\begin{array}{l}\mathrm{HT} \\
\mathrm{DM}\end{array}$ & $\sqrt{ }$ & $\sqrt{ }$ & - & $\begin{array}{c}\text { Tidak } \\
\text { diketah u }\end{array}$ \\
\hline 28 & $\mathrm{~N}_{\mathrm{f}} \mathrm{B}$ & 57 & 9 & $\begin{array}{c}\text { Tidak } \\
\text { diketahui }\end{array}$ & NHS & $\begin{array}{c}\text { Tidak } \\
\text { diketah ui }\end{array}$ & $\underset{H T}{\mathrm{DM}}$ & $\sqrt{ }$ & $\sqrt{1}$ & - & $\begin{array}{c}\text { Tidak } \\
\text { diketah u }\end{array}$ \\
\hline 29 & Tn.H & 59 & 2 & $\begin{array}{c}\text { Tidak } \\
\text { diketahui }\end{array}$ & $\begin{array}{c}\text { lník } \\
\text { Cerebral } \\
\text { Dextra }\end{array}$ & $\begin{array}{l}\text { Tidak } \\
\text { diketah di }\end{array}$ & - & $\sqrt{1}$ & - & $\sqrt{ }$ & $\begin{array}{c}\text { Tidak } \\
\text { diketah u }\end{array}$ \\
\hline 30 & $\operatorname{Tn} R$ & 69 & 2 & $\begin{array}{c}\text { Tidak } \\
\text { diketahui }\end{array}$ & $\begin{array}{c}\text { Infark } \\
\text { Cerebri }\end{array}$ & $\begin{array}{c}\text { Tidak } \\
\text { diketah ui }\end{array}$ & HT & $\sqrt{ }$ & $\sqrt{ }$ & & $\begin{array}{c}\text { Tidak } \\
\text { diketah u }\end{array}$ \\
\hline 31 & $\mathrm{~N}_{f} \mathrm{M}$ & 89 & 9 & $\begin{array}{c}\text { Tidak } \\
\text { diketahui }\end{array}$ & $\begin{array}{c}\text { Infark } \\
\text { Cerebri }\end{array}$ & $\begin{array}{c}\text { Tidak } \\
\text { diketah ui }\end{array}$ & $\begin{array}{l}\mathrm{HT} \\
\mathrm{DM}\end{array}$ & Normal & - & - & $\begin{array}{c}\text { Tidak } \\
\text { diketah u }\end{array}$ \\
\hline 32 & $\mathrm{~N}_{\mathrm{f}} \mathrm{B}$ & 68 h & 9 & $\begin{array}{c}\text { Tidak } \\
\text { diketahui }\end{array}$ & NHS & $\begin{array}{c}\text { Tidak } \\
\text { diketah ui }\end{array}$ & $\begin{array}{l}\text { HT } \\
\text { DM }\end{array}$ & Normal & $\sqrt{1}$ & - & $\begin{array}{c}\text { Tidak } \\
\text { diketah u }\end{array}$ \\
\hline
\end{tabular}




\begin{tabular}{|c|c|c|c|c|c|c|c|c|c|c|c|}
\hline 33 & $\mathrm{Ny} S \mathrm{~S}$ & 86 & 9 & $\begin{array}{c}\text { Tidak } \\
\text { diketah ui }\end{array}$ & NHS & $\begin{array}{c}\text { Tidak } \\
\text { diketah ui }\end{array}$ & $\begin{array}{l}\text { HT } \\
\text { DM }\end{array}$ & Normal & - & & $\begin{array}{c}\text { Tidak } \\
\text { diketah u }\end{array}$ \\
\hline 34 & $\mathrm{~N}_{f} \mathrm{~J}$ & 46 & $?$ & $\begin{array}{c}\text { Tidak } \\
\text { diketah ui }\end{array}$ & $\begin{array}{l}\text { In'serk } \\
\text { Cerebin } \\
\text { Dextra }\end{array}$ & $\begin{array}{c}\text { Tidak } \\
\text { diketah ui }\end{array}$ & $\begin{array}{l}\mathrm{HT} \\
\mathrm{DM}\end{array}$ & Normal & & & $\begin{array}{c}\text { Tidak } \\
\text { diketah u }\end{array}$ \\
\hline 35 & Ny.H & 67 & 9 & $\begin{array}{c}\text { Tidak } \\
\text { diketah ui }\end{array}$ & $\mathrm{NHS}$ & $\begin{array}{c}\text { Tidak } \\
\text { diketah ui }\end{array}$ & DM & $\sqrt{1}$ & & & $\begin{array}{c}\text { Tidak } \\
\text { diketah u' }\end{array}$ \\
\hline 36 & Tn.M & 49 & 2 & $\begin{array}{c}\text { Tidak } \\
\text { diketah ui }\end{array}$ & $\mathrm{NHS}$ & $\begin{array}{c}\text { Tidak } \\
\text { diketah ui }\end{array}$ & HT & $\sqrt{1}$ & $\begin{array}{c}\text { BB:60 } \\
\mathrm{kg}\end{array}$ & Merokok & $\begin{array}{c}\text { Tidak } \\
\text { diketah u' }\end{array}$ \\
\hline 37 & Tn.S & 54 & 8 & $\begin{array}{c}\text { Tidak } \\
\text { diketah ui }\end{array}$ & NHS & $\begin{array}{c}\text { Tidak } \\
\text { diketah ui }\end{array}$ & HT & $\sqrt{ }$ & $\sqrt{ }$ & Merokok & $\begin{array}{c}\text { Tidak } \\
\text { diketah u }\end{array}$ \\
\hline 38 & $\mathrm{Ny} S \mathrm{~S}$ & 53 & $?$ & $\begin{array}{c}\text { Tidak } \\
\text { diketah ui }\end{array}$ & NHS & $\begin{array}{c}\text { Tidak } \\
\text { diketah ui }\end{array}$ & HT & $\sqrt{1}$ & - & Merokok & $\begin{array}{c}\text { Tidak } \\
\text { diketah u }\end{array}$ \\
\hline 39 & Tn.A & 79 & 2 & $\begin{array}{c}\text { Tidak } \\
\text { diketah ui }\end{array}$ & $\begin{array}{c}\text { Lacunar } \\
\text { Intark } \\
\text { Cerebi } \\
\text { Dexra } \\
\text { dan } \\
\text { Atrof } \\
\text { Cerebi }\end{array}$ & $\begin{array}{c}\text { Tidak } \\
\text { diketah ui }\end{array}$ & HT & Normal & - & Merokok & $\begin{array}{c}\text { Tidak } \\
\text { diketah u }\end{array}$ \\
\hline 40 & Ny.H & 53 & ? & $\begin{array}{c}\text { Tidak } \\
\text { diketah ui }\end{array}$ & NAS & $\begin{array}{c}\text { Tidak } \\
\text { diketah ui }\end{array}$ & $\begin{array}{c}\mathrm{DM} \\
\mathrm{HT}\end{array}$ & $\sqrt{1}$ & - & & $\begin{array}{c}\text { Tidak } \\
\text { diketah }\end{array}$ \\
\hline
\end{tabular}

\begin{tabular}{|c|c|c|c|c|c|c|c|c|c|c|c|}
\hline 41 & $\mathrm{NA} A$ & 5 & 9 & $\begin{array}{c}\text { Tidak } \\
\text { dikebah di }\end{array}$ & $\begin{array}{l}\text { llark } \\
\text { Cerebri } \\
\text { Dextra }\end{array}$ & $\begin{array}{c}\text { Tidak } \\
\text { dikebah ui }\end{array}$ & HT & $\sqrt{ }$ & $\sqrt{ }$ & Obat & $\begin{array}{l}\text { Tidks } \\
\text { diketh o }\end{array}$ \\
\hline 42 & Th. & 72 & 8 & $\begin{array}{l}\text { Tidak } \\
\text { diketah of }\end{array}$ & N-5 & $\begin{array}{l}\text { Tidak } \\
\text { dikebh u }\end{array}$ & HT & 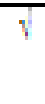 & 8865 & & $\begin{array}{c}\text { Tidek } \\
\text { diketah o: }\end{array}$ \\
\hline 43 & Tп.Y & 51 & D & $\begin{array}{l}\text { Tidak } \\
\text { dikebah u }\end{array}$ & N-6 & $\begin{array}{c}\text { Tidak } \\
\text { dikebh ui }\end{array}$ & $\begin{array}{l}\mathrm{HT} \\
\mathrm{DM}\end{array}$ & $\sqrt{ }$ & - & Merokok & $\begin{array}{l}\text { Tidek } \\
\text { diketah o }\end{array}$ \\
\hline 44 & Tn.T & 84 & $d$ & $\begin{array}{l}\text { Tidak } \\
\text { dikgah u }\end{array}$ & N-5 & $\begin{array}{l}\text { Tidak } \\
\text { dikeblh ai }\end{array}$ & $\mathbb{H T}$ & $\gamma$ & &. & $\begin{array}{c}\text { Tidk } \\
\text { diketh o }\end{array}$ \\
\hline 45 & $\overline{T п . A}$ & 5 & d & $\begin{array}{c}\text { Tidak } \\
\text { dikebah ui }\end{array}$ & NS & $\begin{array}{c}\text { Tidak } \\
\text { dikebh ui }\end{array}$ & $\begin{array}{l}\mathrm{HT} \\
\mathrm{DM}\end{array}$ & $\eta$ & 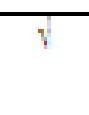 & $\begin{array}{l}\text { Merokok } \\
\text { Alkohol }\end{array}$ & $\begin{array}{c}\text { Tidak } \\
\text { diketah o }\end{array}$ \\
\hline 46 & $\mathrm{NA}$ & 8 & 8 & $\begin{array}{c}\text { Tidak } \\
\text { dikeblh of }\end{array}$ & $\mathrm{N} 6$ & $\begin{array}{c}\text { Tidak } \\
\text { dikeblh ui }\end{array}$ & $\mathrm{HT}$ & $\sqrt{ }$ & 1 & $=$ & $\begin{array}{c}\text { Tiddk } \\
\text { diketh o }\end{array}$ \\
\hline 47 & $M P$ & 60 & 5 & $\begin{array}{l}\text { Tidak } \\
\text { dikelah ui }\end{array}$ & $\begin{array}{l}\text { Multiple } \\
\text { lfark } \\
\text { Cerebri }\end{array}$ & $\begin{array}{c}\text { Tidak } \\
\text { dikebah ui }\end{array}$ & $\begin{array}{l}\mathrm{HT} \\
\mathrm{DM}\end{array}$ & $\sqrt{ }$ & $\checkmark$ & . & $\begin{array}{c}\text { Tidak } \\
\text { diketh o }\end{array}$ \\
\hline
\end{tabular}




\begin{tabular}{|c|c|c|c|c|c|c|c|c|c|c|c|}
\hline 48 & $\mathrm{Ng} \mathrm{S}$ & 62 & $?$ & $\begin{array}{c}\text { Tidak } \\
\text { diketah ui }\end{array}$ & N-5 & $\begin{array}{c}\text { Tidak } \\
\text { diketah ui }\end{array}$ & $\begin{array}{l}\mathrm{HT} \\
\mathrm{DM}\end{array}$ & $\sqrt{1}$ & $\nabla$ & $:$ & $\begin{array}{c}\text { Tidak } \\
\text { diketah }\end{array}$ \\
\hline 49 & Tn. Mp & 70 & 2 & $\begin{array}{c}\text { Tidak } \\
\text { diketah ui }\end{array}$ & $\begin{array}{l}\text { Infark } \\
\text { Cerebi } \\
\text { Sinistra }\end{array}$ & $\begin{array}{c}\text { Tidak } \\
\text { diketah ui }\end{array}$ & HT & Normal & - & Merokok & $\begin{array}{c}\text { Tidak } \\
\text { diketah }\end{array}$ \\
\hline 50 & $T n \cdot 2$ & 17 & d & $\begin{array}{c}\text { Tidak } \\
\text { diketah ui }\end{array}$ & $\begin{array}{l}\text { Iniserk } \\
\text { Cerebi } \\
\text { Dextra }\end{array}$ & $\begin{array}{c}\text { Tidak } \\
\text { diketah ui }\end{array}$ & $\cdot$ & Normal & $\sqrt{ }$ & - & $\begin{array}{c}\text { Tidak } \\
\text { diketah }\end{array}$ \\
\hline 51 & Tn.NG & 40 & 2 & $\begin{array}{c}\text { Tidak } \\
\text { diketah ui }\end{array}$ & NHS & $\begin{array}{c}\text { Tidak } \\
\text { diketah ui }\end{array}$ & HT & v & - & Merokok & $\begin{array}{l}\text { Tidak } \\
\text { diketah }\end{array}$ \\
\hline 52 & Tn Bac & 41 & 2 & $\begin{array}{c}\text { Tidak } \\
\text { diketah ui }\end{array}$ & NHS & $\begin{array}{c}\text { Tidak } \\
\text { diketah ui }\end{array}$ & $\begin{array}{l}\text { DM } \\
\mathrm{HT}\end{array}$ & Normal & $\cdot$ & Nerokok & $\begin{array}{c}\text { Tidak } \\
\text { diketah }\end{array}$ \\
\hline 53 & $\mathrm{Ny}$ Sm & 68 & $?$ & $\begin{array}{c}\text { Tidak } \\
\text { diketah ui }\end{array}$ & $\begin{array}{l}\text { Ifiserk } \\
\text { Cerebi } \\
\text { Dextra }\end{array}$ & $\begin{array}{c}\text { Tidak } \\
\text { diketah ui }\end{array}$ & $\begin{array}{l}\text { HT } \\
\text { DM }\end{array}$ & Normal & $\sqrt{ }$ & - & $\begin{array}{c}\text { Tidak } \\
\text { diketah }\end{array}$ \\
\hline 54 & Tn.Mar & 58 & 2 & $\begin{array}{c}\text { Tidak } \\
\text { diketah ui }\end{array}$ & N-S & $\begin{array}{c}\text { Tidak } \\
\text { diketah ui }\end{array}$ & HT & Normal & $\cdot$ & Merokok & $\begin{array}{c}\text { Tidak } \\
\text { diketah }\end{array}$ \\
\hline
\end{tabular}

\section{Lampiran 02 :}

HASIL PENGOLAHAN DATA MENGGUNAKAN MICROSOFT OFFICE EXCELL

\begin{tabular}{|c|c|c|c|}
\hline $\mathrm{Mec}$ & Inisigl Fasien & Kolesterol Total & Interpretasi \\
\hline-1 & MY.M & $+4,2$ & NormaI \\
\hline 2 & Wrd & 283 & Tingei \\
\hline 3 & $\mathrm{Ny}$ & 215 & Tinggi \\
\hline 4 & Wh & 748 & Norma \\
\hline 5 & $\operatorname{Tr} 4$ & 172 & Normal \\
\hline 6 & Tim. Ny & 194 & Norm $\equiv$ \\
\hline 7 & MrN & 219 & Tingei \\
\hline$B$ & Tin. $\mathbf{F}$ & 273 & Tinggi \\
\hline 9 & $T-\mathrm{T}$ & 200 & Tinggi \\
\hline-10 & Wr- & 177 & Aorma \\
\hline+1 & $\mathrm{Tr} \Xi$ & 179 & Norm: \\
\hline 72 & Tin & 230 & Tingei \\
\hline$=3$ & Why & 237 & Tingei \\
\hline-4 & Ny.S & 357 & Tingei \\
\hline-15 & Ny_E & $2 z+$ & Tinggi \\
\hline-16 & Ny.M & 775 & TormaI \\
\hline-7 & $\mathrm{~N}_{f}=$ & 125 & Norm El \\
\hline$+B$ & Ny.S & 198 & formal \\
\hline 79 & WhIH & 285 & Tingei \\
\hline 20 & $T-\mathrm{TS}$ & 309 & Tingei \\
\hline$z 1$ & Fir $1-1$ & 400 & Tingei \\
\hline 22 & Tr- M & 154 & Norm $\equiv 1$ \\
\hline 23 & Tin 4 & $2 z 4$ & Tinggi \\
\hline 24 & Wy.F & 249 & Tingei \\
\hline 25 & ny-S & 229 & Tingei \\
\hline 26 & Trin & नES & Porma \\
\hline $2 T$ & Ny_L & 137 & Normal \\
\hline 28 & $T-\Xi$ & 145 & Normal \\
\hline 29 & Ny.s & 289 & Tinggi \\
\hline 30 & $\operatorname{Tr} . z$ & 327 & Tinggi \\
\hline 31 & Ny.S & 118 & Norma \\
\hline 32 & Ny.A & 255 & Tinggi \\
\hline 33 & Tin. I & 309 & Tinggi \\
\hline 34 & Nhd & 195 & Normal \\
\hline 35 & Tin.N & 224 & Tinggi \\
\hline 36 & $\operatorname{Tin} A$ & 207 & Tinggi \\
\hline 37 & $\mathrm{Ny}-\mathrm{H}$ & 220 & Tinggi \\
\hline 38 & My.S & 200 & Tingei \\
\hline 39 & Tr..H & 240 & Tinggi \\
\hline 40 & Ny $\mathrm{A}$ & 205 & Tinppi \\
\hline
\end{tabular}




\begin{tabular}{|c|c|c|c|}
\hline 47 & T-M & 270 & Tinggi \\
\hline 42 & $\overline{T n} \cdot \mathbf{F}$ & $2 B T$ & Tinggi \\
\hline 43 & Tin. $H$ & 300 & Tinggi \\
\hline 44 & Tin. $\mathbf{F}$ & 255 & Tinggi \\
\hline 45 & Nys & $2 B 8$ & Tinggi \\
\hline 46 & $T-M$ & 310 & Tinggi \\
\hline 47 & TrLY $\mathrm{Y}$ & 201 & Tingei \\
\hline $4 B$ & $\mathbb{N}_{f-T}$ & 295 & Tingei \\
\hline 49 & Ny.A & $30 \mathrm{~B}$ & Tinggi \\
\hline 50 & $\operatorname{Tin} \triangle A$ & 795 & Normal \\
\hline 51 & Ny.I & 740 & Normal \\
\hline 52 & $\operatorname{Tr} \mathrm{A}$ & 155 & Normal \\
\hline 53 & Tin_A & 785 & Normal \\
\hline 54 & Ny.s & 191 & Normal \\
\hline
\end{tabular}

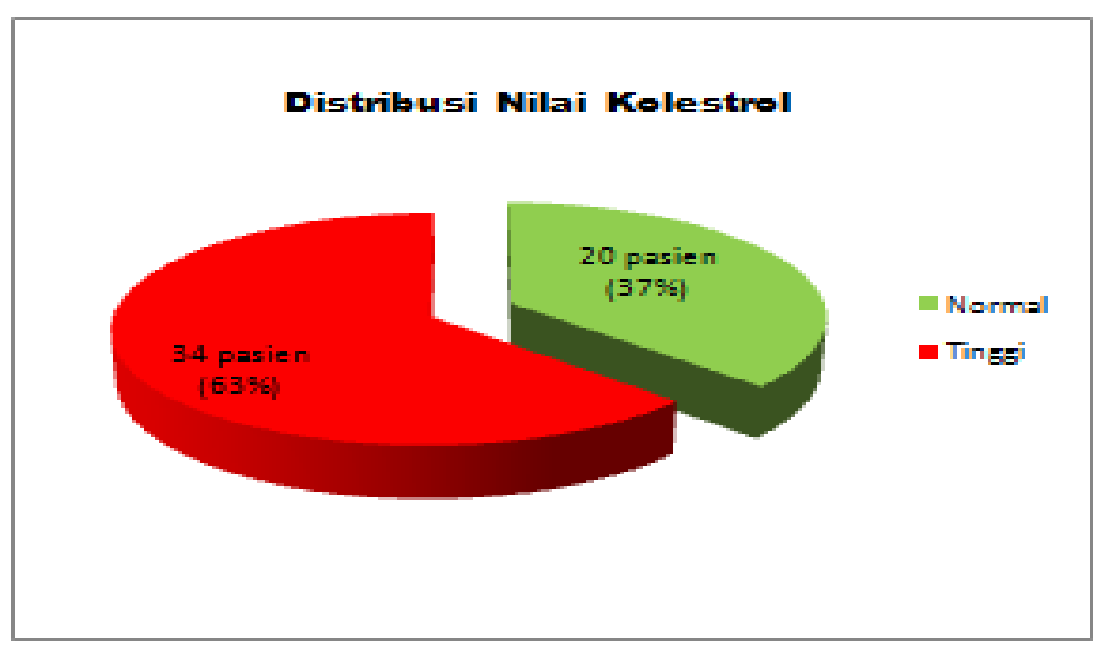

\begin{tabular}{|c|c|c|c|}
\hline No & Heisall Pasilen & LDL & l-oerpne tasii \\
\hline$=$ & $\mathrm{Ny}-\mathrm{M}$ & 57 & Normy $\exists I$ \\
\hline$z$ & Wy D & 739 & Tingei \\
\hline 3 & My.A & 142 & Tingei \\
\hline 4 & Nyr N & $13 \Xi$ & Tingei \\
\hline 5 & Tin.A & 39 & Normal \\
\hline 6 & Tin_.NA & -195 & Tingei \\
\hline 7 & $\mathrm{~N}_{\mathrm{r}} \mathrm{N}$ & 155 & Timgei \\
\hline$B$ & Tin. $\mathbb{R}$ & 212 & Tingei \\
\hline 9 & Tin.E & 123 & Norm $\equiv I$ \\
\hline 10 & Ny $I \mathbb{H}$ & 174 & Tingei \\
\hline 11 & Tin.E & 104 & Norm $\equiv$ I \\
\hline 12 & $T-M$ & 134 & Timegi \\
\hline 13 & Ny $I H$ & 108 & Normal \\
\hline 74 & Ny & 127 & Norm $\equiv I$ \\
\hline 75 & Ny.E & 113 & Nermal \\
\hline 716 & Ny.M & 769 & Tingei \\
\hline-17 & Ny.E & 59 & Normal \\
\hline $7 \mathrm{~B}$ & Ny.s & 780 & Tingei \\
\hline 19 & Norf & 173 & Tingei \\
\hline 20 & Tin.S & 133 & Tingei \\
\hline 21 & Why & 151 & Tingei \\
\hline 22 & Tin & 77 & Normal \\
\hline 23 & Tri. & $17 \mathrm{E}$ & Tingei \\
\hline 24 & Ny.F & 75 & Normal \\
\hline 25 & Ny & 104 & Pormal \\
\hline 26 & ThM & 80 & Normal \\
\hline 27 & Nys.A & 53 & Norm $\equiv \|$ \\
\hline $2 B$ & Trn. $\mathrm{B}$ & 157 & Tingei \\
\hline 29 & Wy & 67 & Normal \\
\hline 30 & $\operatorname{Tr} z$ & 115 & Normal \\
\hline 31 & Ny.S & 149 & Tinggi \\
\hline 32 & Ny.A & 142 & Tinggi \\
\hline 33 & Tin. I & 177 & Tinggi \\
\hline 34 & TrM & 125 & Normal \\
\hline 35 & Ny.A & 170 & Normal \\
\hline 36 & Ny.S & 50 & Normal \\
\hline 37 & Tin. N & 99 & Normal \\
\hline $3 B$ & Tr..A & 131 & Tinggi \\
\hline 39 & Ny $\_$H & 150 & Tingai \\
\hline
\end{tabular}




\begin{tabular}{|c|c|c|c|}
\hline 40 & Tn.A & 0 & Normal \\
\hline 41 & Ny.S & 170 & Tinggi \\
\hline 42 & Tn.H & 160 & Tinggi \\
\hline 43 & Ny.I & 75 & Normal \\
\hline 44 & Tn.M & 135 & Tinggi \\
\hline 45 & Tn.R & 150 & Tinggi \\
\hline 46 & Tn.H & 144 & Tinggi \\
\hline 47 & Tn.R & 134 & Tinggi \\
\hline 48 & Ny.S & 62 & Normal \\
\hline 49 & Tn.S & 133 & Tinggi \\
\hline 50 & Ny.S & 139 & Tinggi \\
\hline 51 & Tn.A & 135 & Tinggi \\
\hline 52 & Ny.T & 155 & Tinggi \\
\hline 59 & Tn. Y & 182 & Tinggi \\
\hline 54 & Tn.A & 65 & Normal \\
\hline
\end{tabular}

\begin{tabular}{|c|c|c|c|}
\hline \multicolumn{4}{|c|}{ Distribusi Nilai LDL } \\
\hline No & |nisial Prasien & HDL & Interpretasi \\
\hline 1 & Ny.M & 251 & Fendah \\
\hline 2 & Ny $D$ & 55 & Normal \\
\hline 3 & Ny.A & 25 & Rendah \\
\hline 4 & $\mathbb{N}_{r} \mathbb{N}$ & 329 & Fendah \\
\hline 5 & $\operatorname{Tin} \cdot \mathbf{A}$ & 39 & Fiendah \\
\hline 5 & Tin.N $\mathbf{N}$ & 51 & Normal \\
\hline 7 & Ny $\mathbb{N}$ & 60 & Normal \\
\hline 8 & $\mathrm{Tn} . \mathrm{R}$ & 48 & Normal \\
\hline 9 & ThE & 45 & Normal \\
\hline 10 & $\mathbb{N}_{r} \cdot H$ & 35 & Rendah \\
\hline 11 & $\operatorname{Tn} B$ & 64 & Normal \\
\hline 12 & TnM M & 48 & Normal \\
\hline 13 & Nyr.H & 50 & Normal \\
\hline 14 & Ny.s & 75 & Normal \\
\hline 15 & Ny.B & 535 & Normal \\
\hline 16 & Ny.M & 24 & Fiendah \\
\hline 17 & Ny.B & 447 & Normal \\
\hline 18 & Ny.s & 42 & Normal \\
\hline 19 & Nyr.H & 23 & Fiendah \\
\hline 20 & $\operatorname{Tn} M$ & 77 & Normal \\
\hline 21 & Wyr.H & 50 & Normal \\
\hline 22 & ThM M & 39 & Rendah \\
\hline 23 & $\operatorname{Tin} \_\mathrm{A}$ & 40 & Normal \\
\hline 24 & Ny.P & 37 & Rendah \\
\hline 25 & Ny.S & 772 & Normal \\
\hline 26 & $\operatorname{Tn} \mathbb{M}$ & 53 & Normal \\
\hline 27 & Ny.A & 38 & Rendah \\
\hline $2 z$ & $\operatorname{Tin} \Xi$ & 45 & Normal \\
\hline
\end{tabular}




\begin{tabular}{|c|c|c|c|}
\hline 23 & Ny.S & 20 & Rendah \\
\hline 30 & $\operatorname{Tr} 2$ & 71 & Normal \\
\hline 31 & Ny & 44,7 & Normal \\
\hline 32 & Ny.A & 592 & Normal \\
\hline 3 & $\operatorname{Tn} s$ & 20 & Rendah \\
\hline 34 & $\mathbb{N y H}$ & 23 & Rendah \\
\hline 35 & Th.A & 40 & Normal \\
\hline 35 & $\mathrm{NyN}$ & 82 & Norma \\
\hline 37 & T=A & 63 & Normal \\
\hline 3 & Ny.I & 52 & Normal \\
\hline 35 & Tin.N $\mathbf{N}$ & 27 & Rendah \\
\hline 40 & Tin.A & $B 7$ & Norm: $=1$ \\
\hline 41 & Ny.H & 41 & Rendar \\
\hline 4.2 & Wys & 55 & Norma \\
\hline 43 & Tin. H & 20 & Rendar \\
\hline 44 & TIn.A & 43 & Rendar \\
\hline 45 & Tin. M & 33 & Rendat \\
\hline 46 & Tin. $\mathbb{R}$ & 35 & Rendar \\
\hline 47 & Tin. $\mathrm{H}$ & 40 & Rendar \\
\hline $4 B$ & Tin. $\mathrm{R}$ & 52 & Normal \\
\hline 49 & Ny.S & 39 & Rendar \\
\hline 50 & TIM.A & $5 \pi$ & Norma \\
\hline 51 & Tin." & B1 & Normal \\
\hline 52 & Ny.T & 65 & Normal \\
\hline 53 & Ny.A & 74 & Normal \\
\hline 54 & Ny S & 69 & Normal \\
\hline
\end{tabular}

Distribusi Nilai HDL

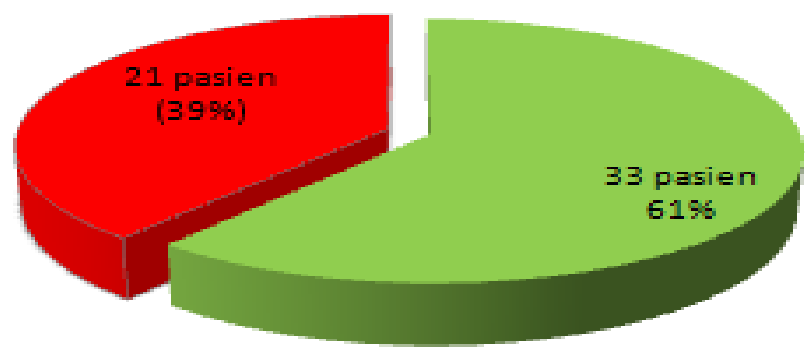

- Normal

nendah

\begin{tabular}{|c|c|c|c|}
\hline No & Inisial Pasien & Trigliserida & l-terpre tasi \\
\hline 1 & Ny.M & 105 & Nomel \\
\hline 2 & Ny D & 291 & Tinggi \\
\hline 3 & Ny.A & 210 & Tinggi \\
\hline 4 & $\mathbf{N y} \mathbb{N}$ & 189 & Nomal| \\
\hline 5 & Th_A & 303 & Tinggi \\
\hline 5 & $\overline{T i n} . \mathbb{N}$ & 134 & Noma! \\
\hline 7 & $\mathbb{N} / \mathbb{N}$ & 240 & Tinggi \\
\hline 8 & $\operatorname{Tin} . \mathbf{R}$ & 184 & Nomal \\
\hline 9 & ThE & 206 & Tinggi \\
\hline 10 & $\mathrm{Ny} \cdot \mathrm{H}$ & 173 & Noma! \\
\hline 11 & $\operatorname{Tn} B$ & 41 & Noma|| \\
\hline 12 & ThM & 123 & Nome!l \\
\hline 13 & $\mathbb{N y} \Perp$ & 147 & Nome! \\
\hline 14 & Ny.s & 158 & Nomal| \\
\hline 15 & Ny.B & 186 & Nomal \\
\hline
\end{tabular}




\begin{tabular}{|c|c|c|c|}
\hline 16 & Py.M & -65 & Norme! \\
\hline 17 & Ny.E & B1 & Nome! \\
\hline 18 & hy.s & 94 & Nemnel \\
\hline 19 & WhI & 139 & Nemne \\
\hline 20 & Tins & 200 & Nome! \\
\hline 21 & Wy-I & 369 & Tingei \\
\hline 22 & $\mathrm{Tr} M$ & $7=0$ & Nome \\
\hline 23 & Tin_A & 743 & Nume \\
\hline 24 & fy.F & 47 & Nomn! \\
\hline 25 & Ny.S & 222 & Tinggi \\
\hline 25 & Tin & 705 & Nome \\
\hline 27 & Ny.s & +10 & Nome \\
\hline 28 & 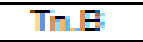 & $6 \bar{B}$ & Alome! \\
\hline 29 & Ny.S & 121 & Alome \\
\hline 30 & $T-z$ & 279 & Tingei \\
\hline 31 & Wy & 276 & Tinggi \\
\hline 32 & My.A & 259 & Tingei \\
\hline 33 & Tr. Ir & 107 & Homn \\
\hline 34 & Ny.S & 45 & Nomn! \\
\hline 33 & Trn. fl & $74 B$ & Womel \\
\hline 35 & Tin & 120 & Alomne \\
\hline 37 & Tr.A & 201 & Tinggi \\
\hline 38 & Ny.I & 253 & Tingei \\
\hline 39 & Tin. I & 231 & Tingai \\
\hline 40 & Tin.A & 250 & Tingei \\
\hline 41 & Ny.H & 170 & Nome \\
\hline 42 & Ny-S & 205 & Tingei \\
\hline 43 & Tr. $\mathrm{H}$ & 110 & Nome \\
\hline 44 & Tin.A & 733 & Nomn: \\
\hline 45 & Tin.M & 740 & Nome! \\
\hline 46 & Tin. $\mathrm{F}$ & 209 & Tinggi \\
\hline 47 & Tin.H & 223 & Tinggi \\
\hline $4 B$ & Tin. $\mathrm{F}$ & 717 & Nome \\
\hline 49 & Ny.S & 130 & Nome \\
\hline 50 & Tr..A & 190 & Neme \\
\hline 51 & Ny.T & 735 & Nome \\
\hline 52 & Ny.A & 285 & Tinggi \\
\hline 53 & Tin.M & 105 & Nome \\
\hline 54 & Ny.s & 73 & Nume \\
\hline
\end{tabular}

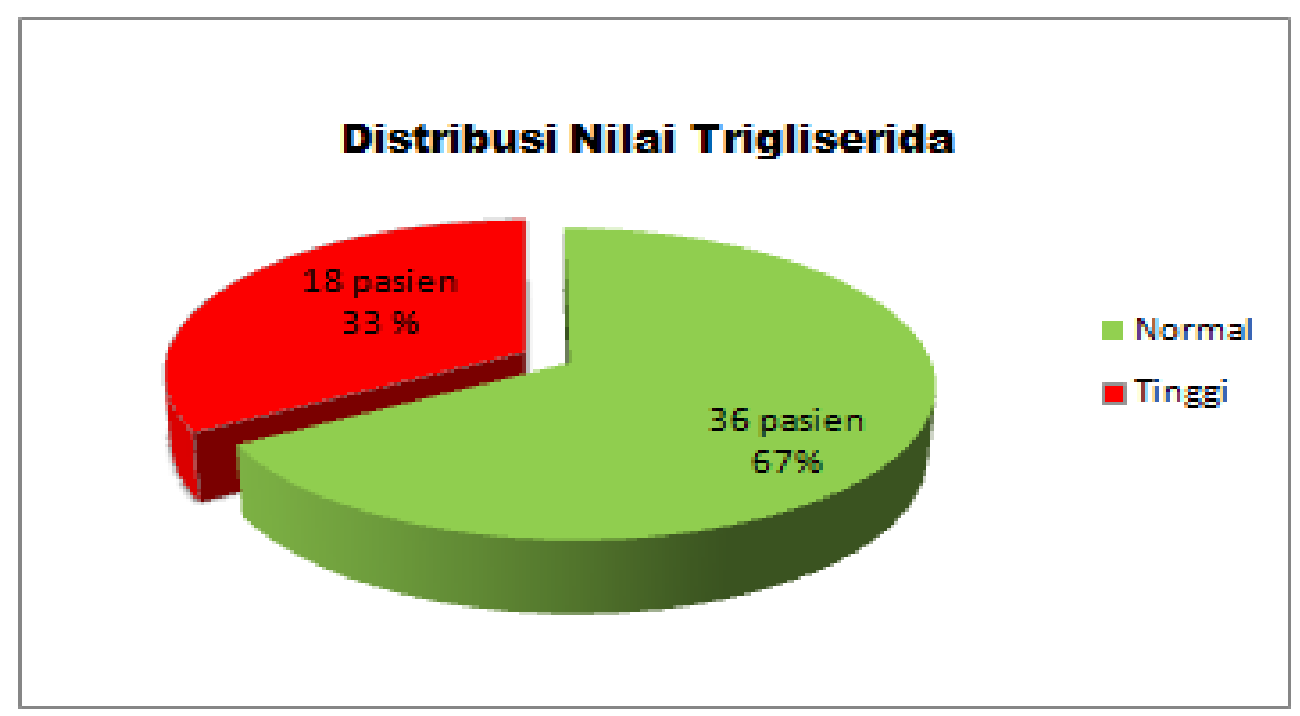




$\begin{array}{ccccc} & \text { Kolesterol } & & & \\ \text { Total } & \text { LDL } & \text { HDL } & \text { Trigliserida } \\ \text { Normal } & 37 \% & 43 \% & 61 \% & 67 \% \\ \text { Tidak Normal } & 63 \% & 57 \% & 39 \% & 33 \%\end{array}$

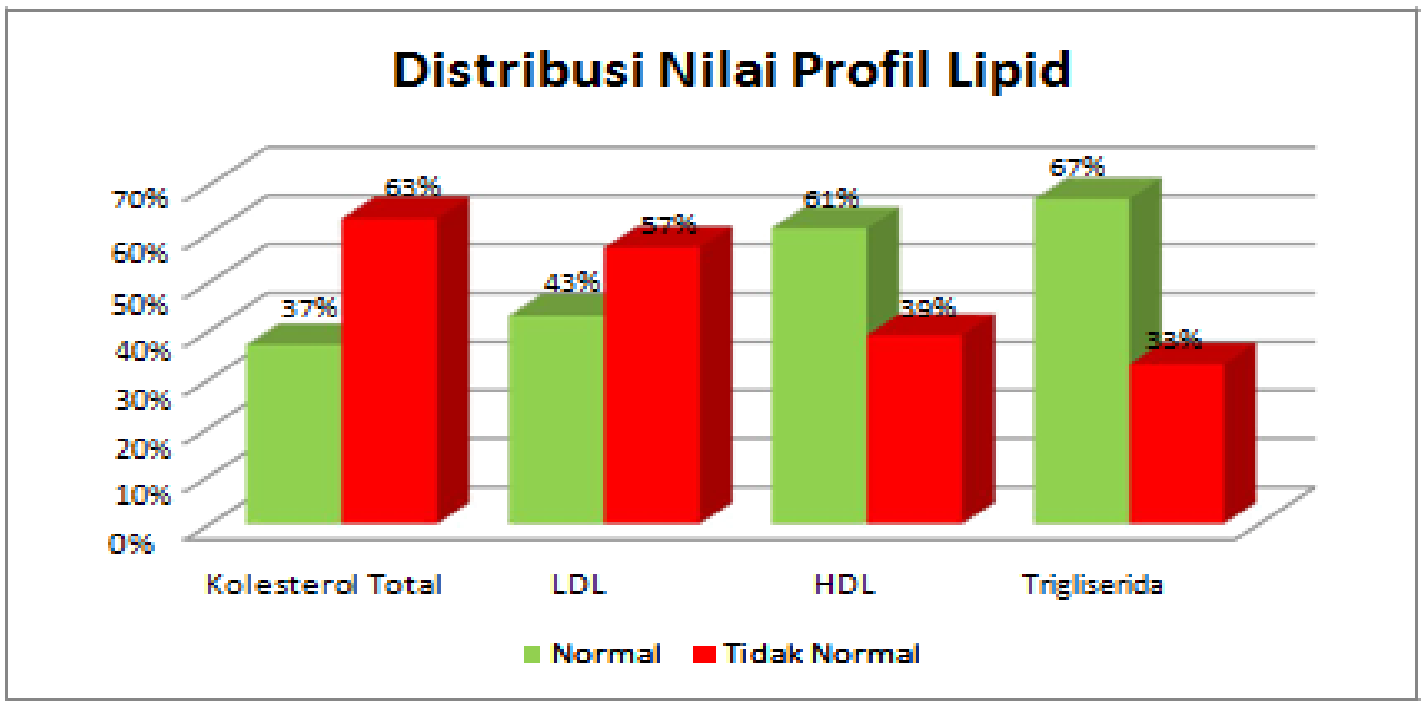

Profil Lipid Laki-laki (Kadar Normal) Perempuan (Kadar Normal) Laki-laki (Kadar Tidak Normal) Perempuan (Kadar Tidak Normal)

\begin{tabular}{|l|l|l|l|l|}
\hline Kolesterol Tota & $30 \%$ & $70 \%$ & $47 \%$ & $53 \%$ \\
\hline LOL & $43 \%$ & $57 \%$ & $52 \%$ & $48 \%$ \\
\hline HDL & $48 \%$ & $52 \%$ & $43 \%$ & $57 \%$ \\
\hline Trigliserida & $50 \%$ & $50 \%$ & $44 \%$ & $56 \%$ \\
\hline
\end{tabular}

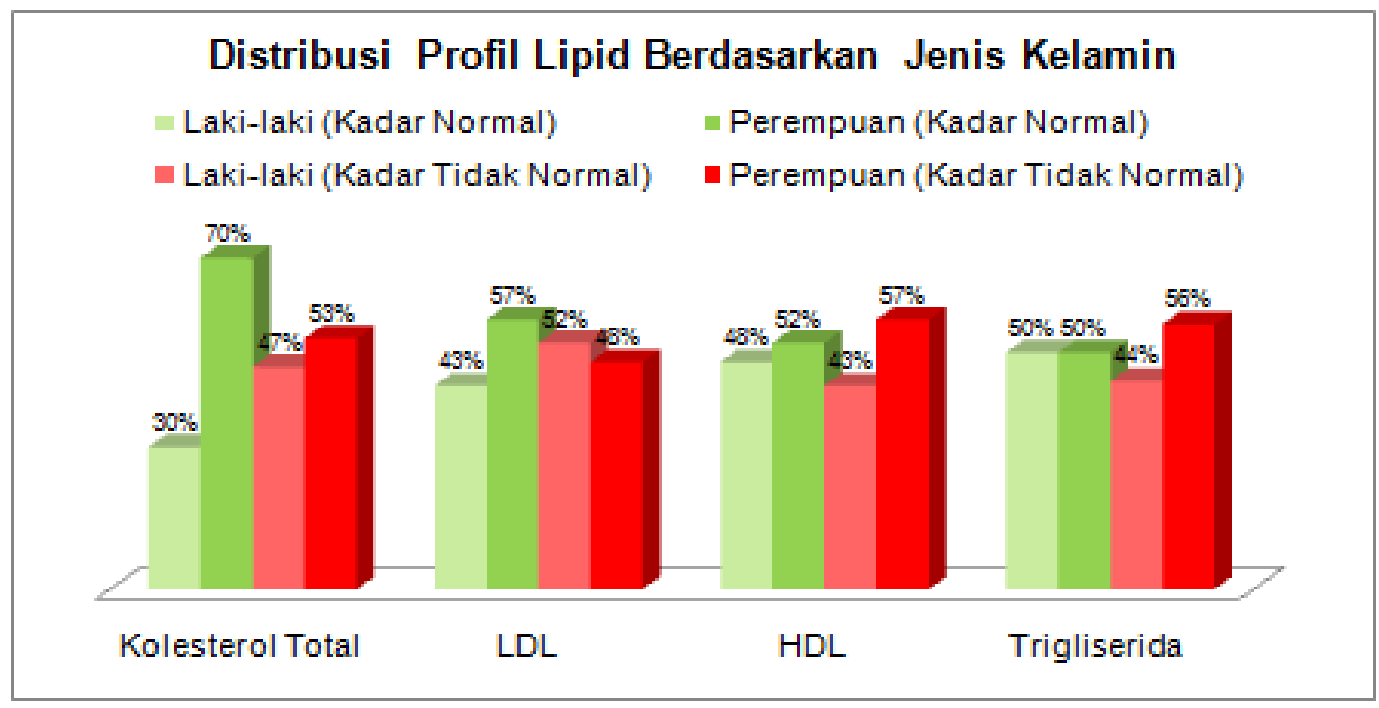




\section{Lampiran 03}

SURAT PERMOHONAN IZIN PENELITIAN

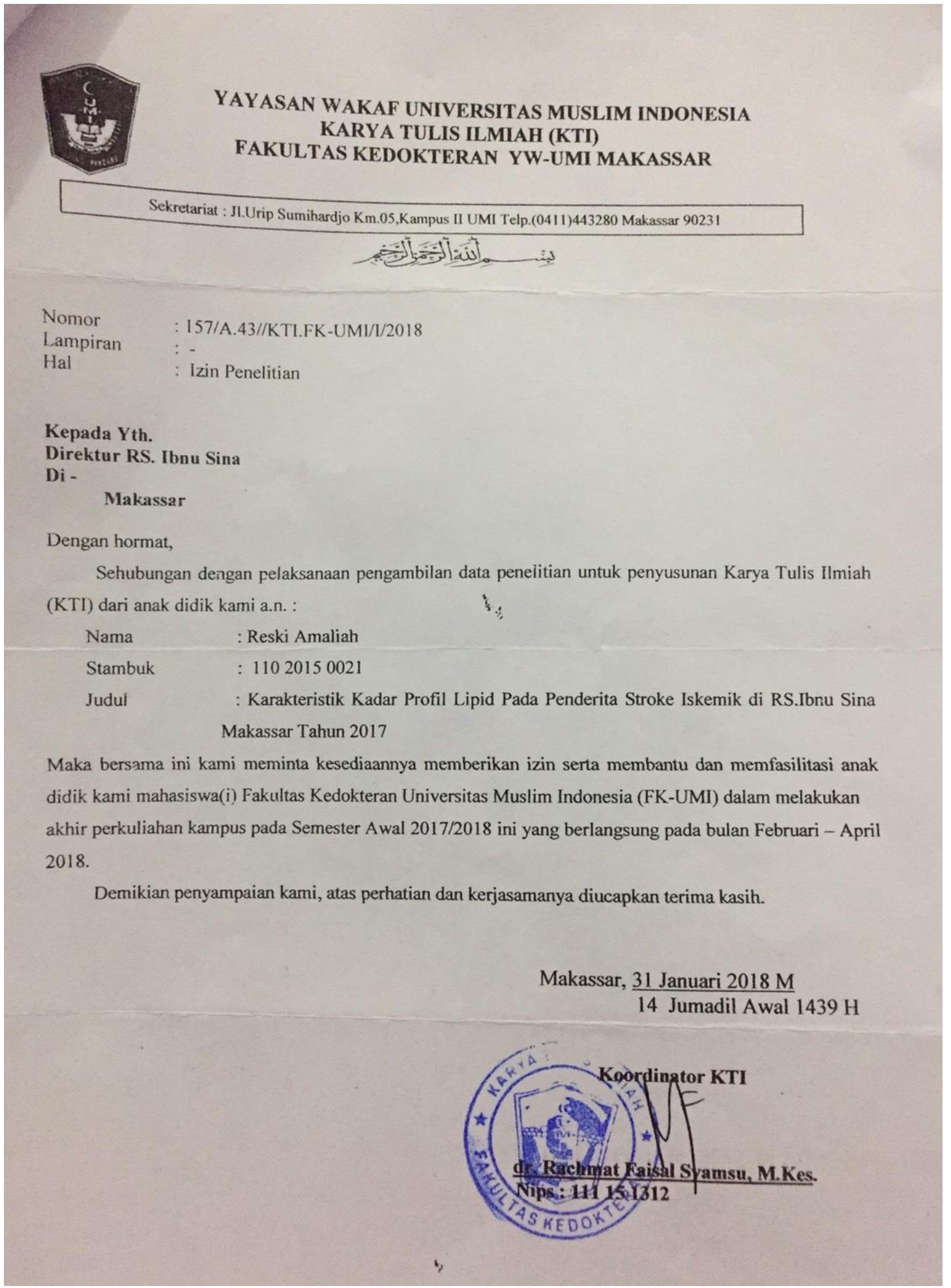




\section{Lampiran 04}

SURAT PERMOHONAN PENGAMBILAN DATA REKAM MEDIS

\section{"IBNU SINA" HOSPITAL \\ TEACHING HOSPITAL \\ OF UMI FOUNDATION}
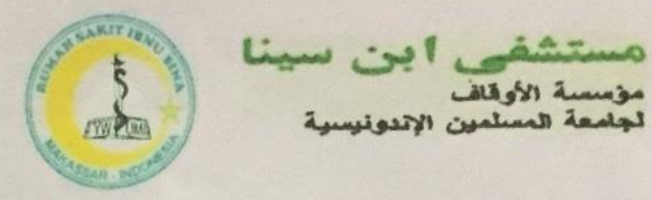

a

RUMAH SAKIT

"IBNU SINA"

RUMAH SAKIT PENDIDIKAN YAYASAN WAKAF UMI

J1. Urip Sumohario Km. 05 №. 264 Telp, (0411) 452917 - 452958 FAX. (0411) 425397 e-mail ibnusinahospoyahoo.co.id Makassar - Indonesia

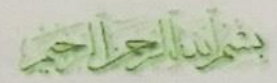

No : 007/DIKLAT/RS.IBSI/YW-UMI/II/2018

Lamp

Hal : Penyampaian

Kepada Yth.

Koord. Rekam Medis

$\mathrm{Di}$ -

RS."Ibnu Sina" Makassar

Assalamu Alaikum Wr. Wb

Dengan Rahmat Allah SWT, sehubungan dengan surat dari Koordinator KTI FK UMI, No : 157/A.43//KTI-FK-UMI//2018 perihal: Pengambilan Data, maka dengan ini kami sampaikan bahwa :

Nama : Rezki Amaliah

Nim : 11020150021

Mohon kiranya dibantu untuk kegiatan tersebut, dan akan dilaksanakan 9 - 13 Februari 2018.

Demikian surat ini diberikan untuk dipergunakan sebagaimana mestinya.

Makassar, 9 Februari 2018

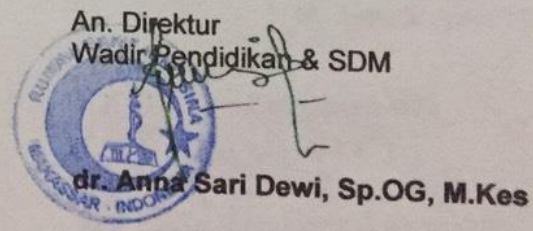

Cc. Arsip 


\section{SURAT REKOMENDASI PERSETUJUAN ETIK}

\section{Komisi Etik Penelitian Kesehatan}

Universitas Muslim Indonesia dan Rumah Sakit Ibnu Sina YW-UMI

(KEPK UMI dan RSIS YW-UMI Makassar)

Jalan Urip Somolar 90231

Website: www umi ac. id, Email: www kepk $a$ umi ac. id

\section{REKOMENDASI PERSETUJUAN ETIK (Expedited)}

Nomor : :060/A.1/KEPK-UMI/I/2018

Berdasarkan Pemeriksaan Protokol dan Dokumen yang berhubungan dengan Protokol Penelitian:
Nama Peneliti : Reski Amaliah
Judul Penelitan : Karakteristik Kadar Profil Lipid pada Penderita Stroke Iskemik di
Rumah Sakit Ibnu Sina Makassar Tahun 2017

No Register

\begin{tabular}{|l|l|}
\hline $\mathrm{U}$ & $\mathrm{M}$ \\
\hline
\end{tabular} Telah di

$$
\begin{array}{ll}
\text { No Versi } & : 1 \\
\text { No PSP } & : 1
\end{array}
$$

Berdasarkan hasil pemeriksaan reviewer, maka Pengurus KEPK UMI dan Rumah Sakit Ibnu Sina memberikan Persetujuan / Rekomendasi Etik untuk Pelaksanaan Penelitian tersebut di atas sampai dengan Tanggal 23 Februari 2019

Dalam melaksanakan penelitian ini, Peneliti diminta untuk menjaga dan menghormati martabat makhluk hidup (Manusia / Hewan Coba) yang menjadi subyek / responden / informan dalam penelitian ini. Dengan demikian diharapkan masyarakat luas dapat memperoleh manfaat yang baik dari penelitian ini.

Pada akhir penelitian, laporan pelaksanaan penelitian harus diserahkan kepada KEPK UMI dan RSIS YW-UMI Makassar. Jika ada perubahan protokol dan atau perpanjangan penelitian, harus mengajukan kembali permohonan kajian etik penelitian (amandemen protokol).

Makassar, 23 Februari 2018

\section{Pengurus KEPK UMI - RS IBSI YW UMI}

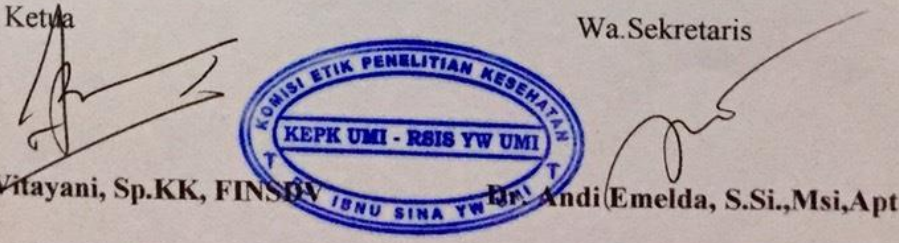




\title{
Lampiran 06
}

\section{SURAT PENYAMPAIAN UJIAN SEMINAR PROPOSAL}

\author{
YAYASAN WAKAF UMI \\ FAKULTAS KEDOKTERAN \\ MEDICAL EDUCATION UNIT \\ KARYA TULIS ILMIAH
}

Sekretariat : JI.Urip Sumihardjo Km.05,Kampus II UMI Telp.(0411)443280 Makassar 90231

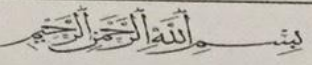

\footnotetext{
Nomor : 706/A.43/KTI-FK UMIXII/2017

Lampiran : 1 rangkap

Hal : Penyampaian jadwal presentasi / Seminar Proposal KTI
}

Kepada,

YTH. Dosen Pembimbing / Penguji Karya Tulis Ilmiah (KTI)

di,

Tempat.

Assalamu Alaikum Warahmatullahi Wabarakatuh

Dengan hormat,

Sehubungan dengan pelaksanaan presentasi dan Seminar Proposal Karya Tulis Ilmiah (KTI)

Semester Awal 2017 / 2018 yang Insya Allah akan diselenggarakan pada :

$\begin{array}{ll}\text { Hari / Tanggal } & \text { : Jumat / 22 Desember } 2017 \\ \text { Waktu } & : \text { 13.00. - selesai WITA } \\ \text { Tempat } & \text { : Ruang KTI Lt.02 Perpustakaan }\end{array}$

Untuk itu kami mohon kesediaan bpk/ibu dosen untuk hadir pada acara tersebut baik sebagai pembimbing dan atau sebagai penguji sebagaimana jadwal terlampir. Demikian surat ini kami sampaikan, atas perhatian dan kerjasamanya diucapkan terima kasih, semoga Allah memberikan rahmat tak terhingga dan menghitungnya sebagai amal jariyah bagi kita semua. Aamiin.

Wassalamu Alaikum Warahmatullahi Wabarakatuh.

Makassar, 20 Desember $2017 \mathrm{M}$

01 Rabiul Akhirl 1439 H

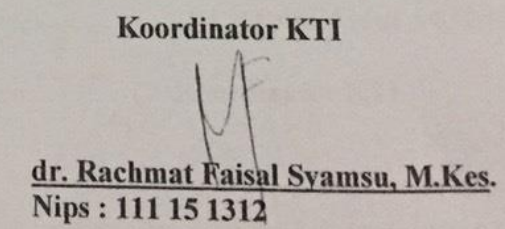

Catatan

- Waktu ujian disesuaikan dengan jadwal akademik yang sedang berlangsung

- Pembacaan/ujias dilaksanakan dengan minimal dihadiri 2 pembimbing dan 1 penguji atau 1 pembimbing dan 2 penguji

Pembacaan/ujian yang tidak dihadiri salah satu penguji/pembimbing sesuai syarat nomer 2 sampai selesai maka tidak boleh ditutup daa segera melaper ke Kord. KTI untuk dicarikan pengeanti. 
SURAT PENYAMPAIAN UJIAN SEMINAR HASIL

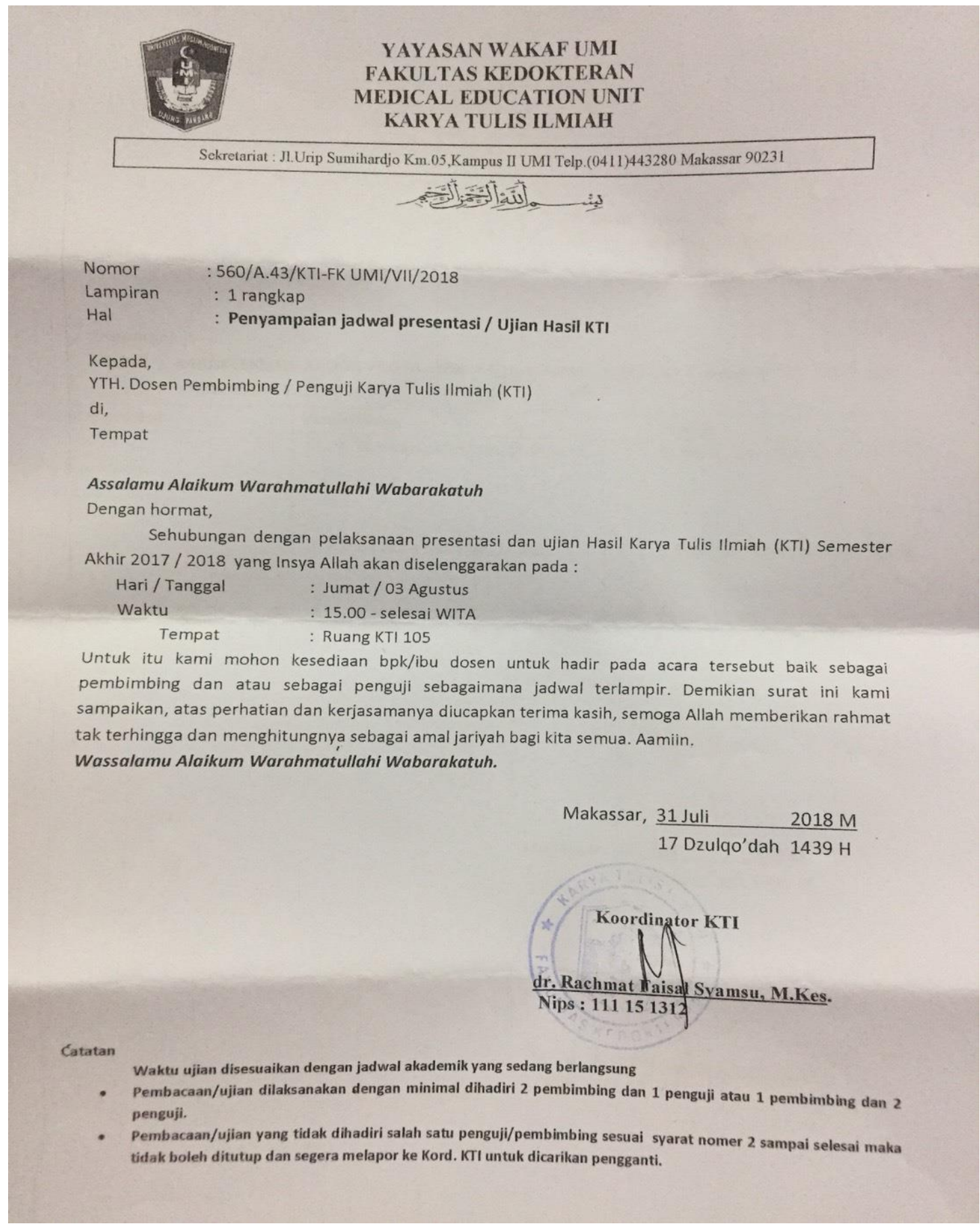




\section{Lampiran 08}

\section{SURAT PENYAMPAIAN UJIAN TUTUP}

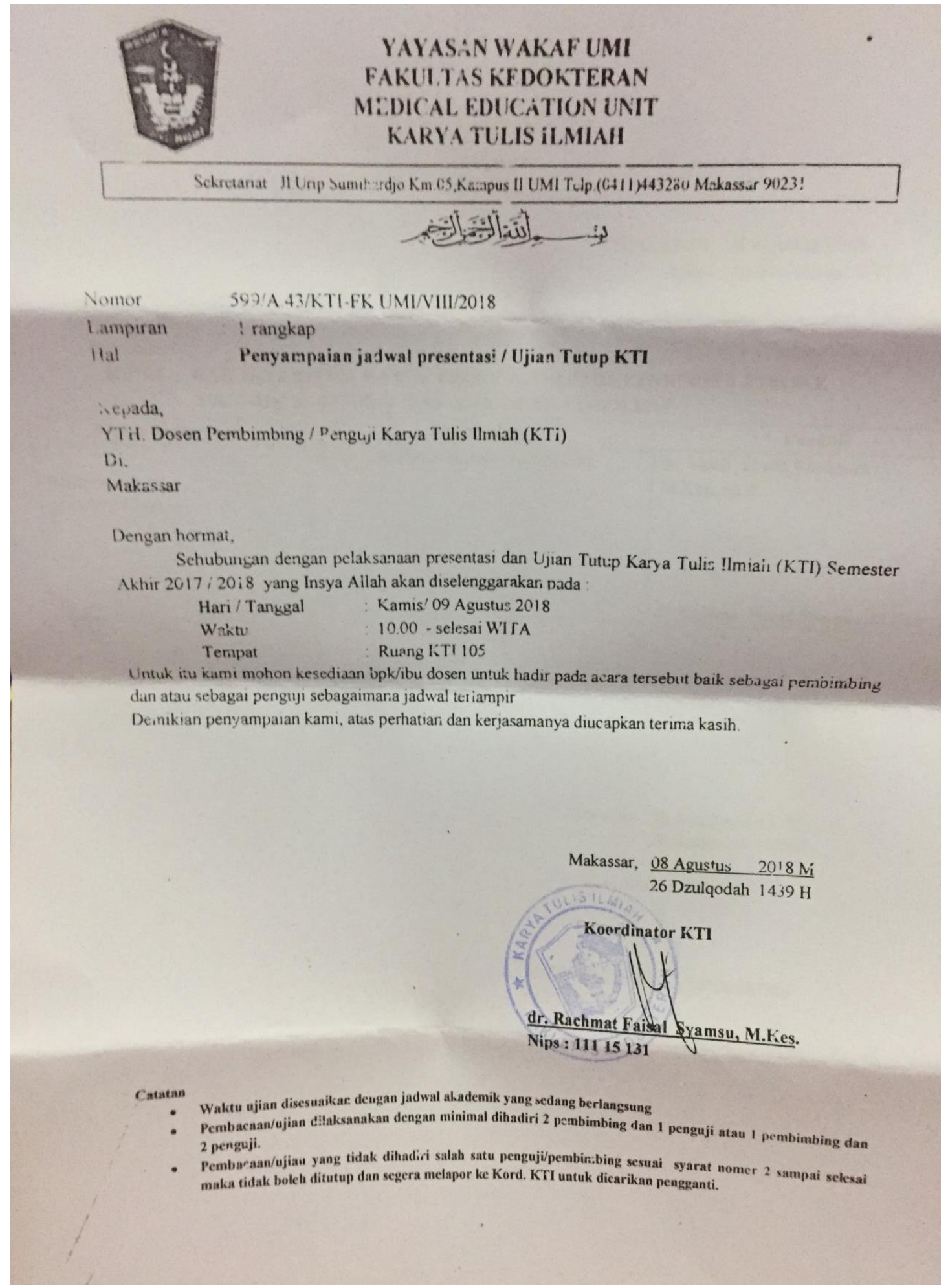




\section{Lampiran 08}

DOKUMENTASI PENELITIAN
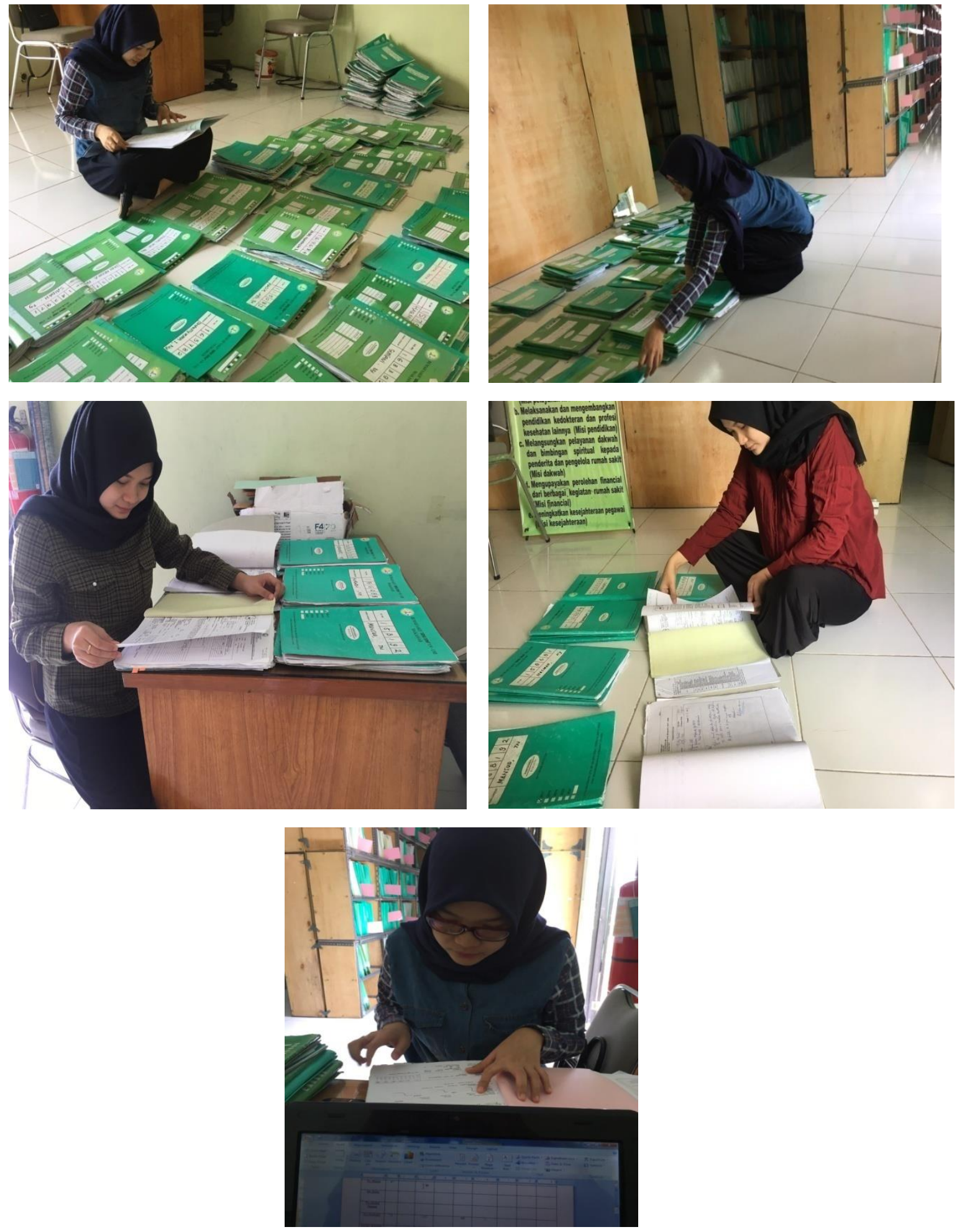